URANIUM MiLl TAILINGS

Remedial Action Project

SuRfaCe PROJECt MANAgement

PLAN

DRAFT

September 1994 


\section{DISCLAIMER}

Portions of this document may be illegible in electronic image products. Images are produced from the best available original document. 


\title{
URANIUM MILL TAILINGS REMEDIAL ACTION PROJECT SURFACE PROJECT MANAGEMENT PLAN
}

This document supersedes document No. UMTRAIDOE-AL-400125.000

\author{
Prepared for \\ U.S. Department of Energy \\ UMTRA Project Office \\ Albuquerque, New Mexico \\ Prepared by \\ Jacobs Engineering Group Inc. \\ Albuquerque, New Mexico
}

\section{DISCLAIMER}

This report was prepared as an account of work sponsored by an agency of the United States Government. Neither the United States Government nor any agency thereof, nor any of their employees, makes any warranty, express or implied, or assumes any legal liability or responsibility for the accuracy, completeness, or usefulness of any information, apparatus, product, or process disclosed, or represents that its use would not infringe privately owned rights. Reference herein to any specific commercial product, process, or service by trade name, trademark, manufacturer, or otherwise does not necessarily constitute or imply its endorsement, recommendation, or favoring by the United States Government or any agency thereof. The views and opinions of authors expressed herein do not necessarily state or reflect those of the United States Government or any agency thereof. 


\section{FOREWORD}

This Project Management Plan describes the planning, systems, and organization that shall be used to manage the UMTRA Surface Project. The plan shall be effective for the Project's duration and shall be reviewed annually and updated as significant changes in Project direction occur. 
TABLE OF CONTENTS

Section

Page

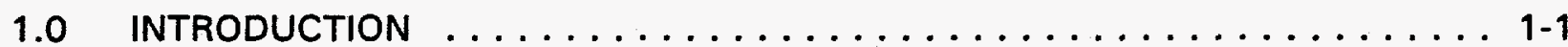

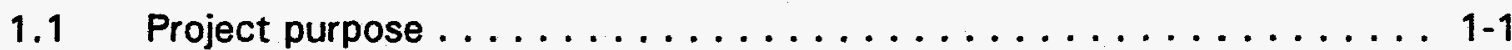

1.2 Project scope ......................... 1-1

1.3 Project management $\ldots \ldots \ldots \ldots \ldots \ldots \ldots \ldots \ldots \ldots \ldots \ldots \ldots$

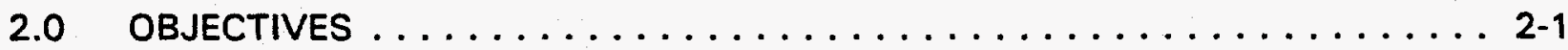

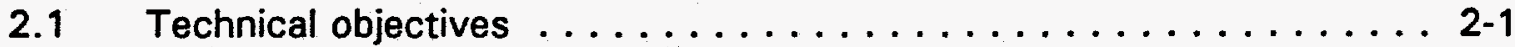

2.2 Cost objectives ........................ 2-1

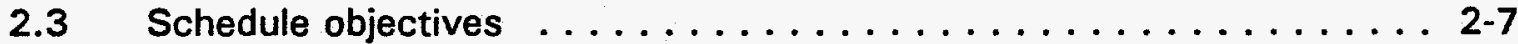

3.0 MANAGEMENT ORGANIZATION AND RESPONSIBILITIES $\ldots \ldots \ldots \ldots \ldots \ldots$

$3.1 \quad$ Project responsibilities . . . . . . . . . . . . . . . . 3-1

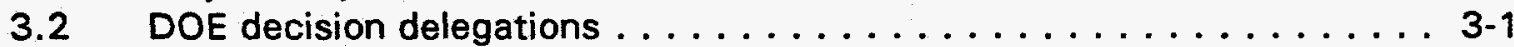

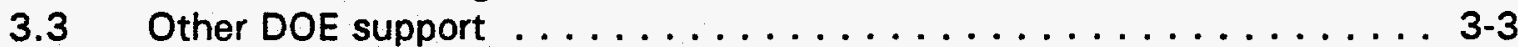

3.3.1 Office of General Council . . . . . . . . . . . . . . . 3-3

3.3.2 Assistant Secretary for Environment, Safety, and Health . . . . 3-3

3.4 Other federal agencies . . . . . . . . . . . . . . . . . . 3-3

3.4.1 Nuclear Regulatory Commission ............... 3-3

3.4.2 U.S. Environmental Protection Agency . . . . . . . . . . . . 3-4

3.4.3 U.S. Department of the Interior ............. 3-4

3.4.4 Other federal agencies .................. 3-5

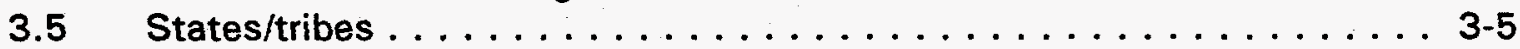

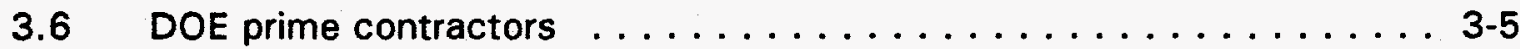

3.6.1 Technical Assistance Contractor . . . . . . . . . . . . 3-5

3.6.2 Remedial Action Contractors . . . . . . . . . . . . . 3-6

3.6.3 Inclusion Survey Nerification Contractor . . . . . . . . . . 3-6

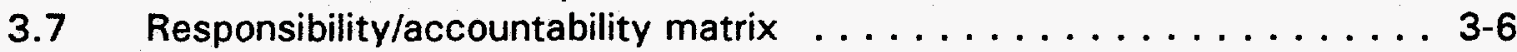

3.8 Manpower requirements .................... 3-6

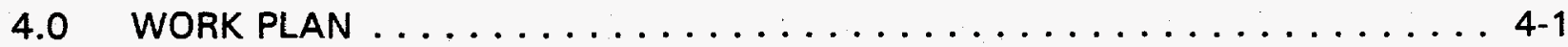

4.1 Introduction ........................ 4 .1

4.2 Work breakdown structure ..................... 4-1

4.3 Project phasing . . . . . . . . . . . . . . . . . . . . 4-1

4.4 Logic diagram . . . . . . . . . . . . . . . . . . 4-4

5.0 PROJECT MANAGEMENT, MEASUREMENT, AND PLANNING

AND CONTROL SYSTEMS $\ldots \ldots \ldots \ldots \ldots \ldots \ldots \ldots \ldots \ldots \ldots \ldots \ldots$

5.1 Introduction .......................... $5 . \ldots \ldots$

5.2 The integrated project management system . . . . . . . . . . 5-1

5.3 Baseline control .......................... 5-2

5.3.1 Cost Baseline Control . . . . . . . . . . . . . . . . 5 5-2

5.3 .2 Schedule Baseline Control ................... 5-2

5.3.3 Technical Baseline Control ... . . . . . . . . . . . . . 5 5-4

5.4 Funds control ........................ $5-4$ 
TABLE OF CONTENTS (Concluded)

Section

Page

$5.5 \quad$ Risk management $\ldots \ldots \ldots \ldots \ldots \ldots \ldots \ldots \ldots \ldots \ldots \ldots \ldots \ldots$

5.5 .1 Sources of risk .................... 5-5

5.5 .2 Contingency control . . . . . . . . . . . . 5-5

6.0 INFORMATION AND REPORTING $\ldots \ldots \ldots \ldots \ldots \ldots \ldots \ldots \ldots \ldots$

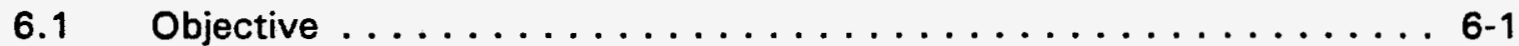

6.2 Technical information .................... 6.1

6.3 Management information ...................... 6-1

6.4 Project reporting ......................... 6-1

6.4 .1 Internal reporting ..................... 6-1

6.4 .2 External reporting ....................... 6-5

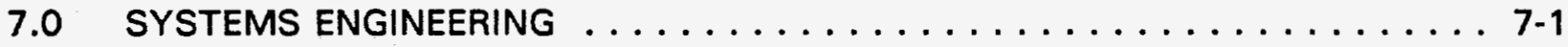

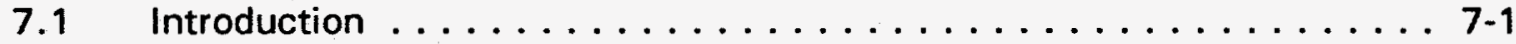

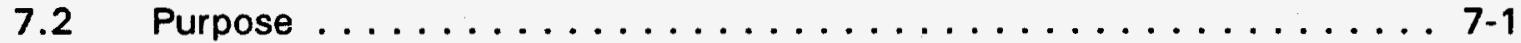

7.3 Project operation . . . . . . . . . . . . . . . . .

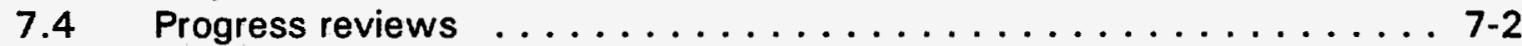

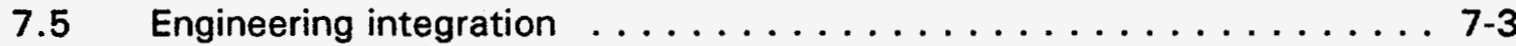

8.0 CONFIGURATION MANAGEMENT $\ldots \ldots \ldots \ldots \ldots \ldots \ldots \ldots \ldots$

8.1 Introduction ....................... 8 .1

8.2 Configuration management plan ................. 8 .1

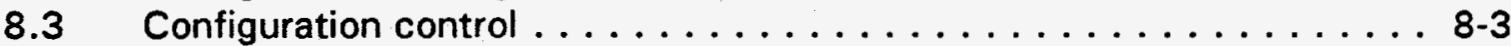

8.3.1 Technical baseline documentation ............. 8-3

8.3.2 Technical baseline control process . . . . . . . . . . . . 8 8-4

8.4 Document control . . . . . . . . . . . . . . . . . . . 8 8

8.5 Records management $\ldots \ldots \ldots \ldots \ldots \ldots \ldots \ldots \ldots \ldots$

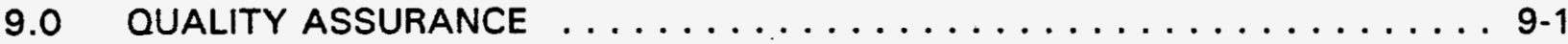

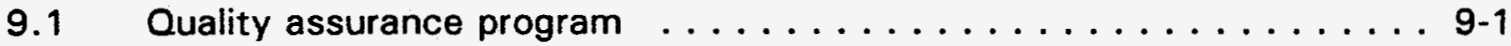

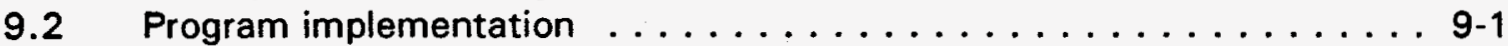

10.0 ENVIRONMENT, SAFETY AND HEALTH $\ldots \ldots \ldots \ldots \ldots \ldots \ldots \ldots \ldots$

10.1 Environment, safety and health program . . . . . . . . . . . 10-1

10.2 Program implementation .................... 10-1

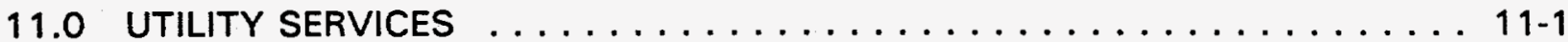

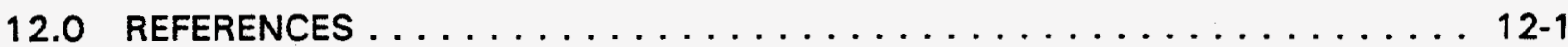

13.0 SUBMISSIONS AND APPROVAL $\ldots \ldots \ldots \ldots \ldots \ldots \ldots \ldots$

ATTACHMENT UMTRA SURFACE PROJECT PLANNING DOCUMENTATION . . . . . A A-1 


\section{LIST OF FIGURES}

Figure

Page

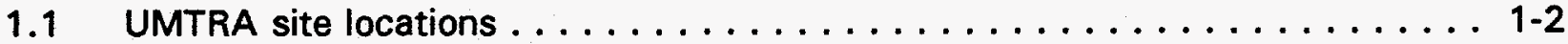

2.1 UMTRA Surface Project schedule FY96 budget submittal . . . . . . . . . . 2-9

2.2 UMTRA Surface Project proposed baseline resources plan FY96 budget

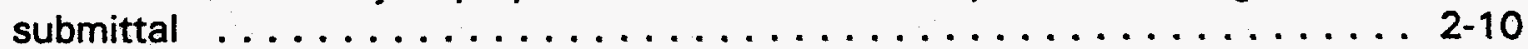

3.1 UMTRA Surface Project organization . . . . . . . . . . . . . . $3-2$

3.2 UMTRA Surface Project staffing plans . . . . . . . . . . . . . . 3-9

4.1 UMTRA Surface Project work breakdown structure . . . . . . . . . . 4-2

4.2 UMTRA Surface Project work breakdown structure by activity data sheet . . . 4-3

4.3 UMTRA Surface Project phases and key decisions ... . . . . . . . 4-5

4.4 UMTRA Surface Project functional workflow . . . . . . . . . . . 4-7

8.1 UMTRA Surface Project configuration management baseline components . . . 8-2

10.1 UMTRA Surface Project ES\&H Program $\ldots \ldots \ldots \ldots \ldots \ldots \ldots \ldots$ 


\section{LIST OF TABLES}

Table

Page

2.1 Summary of EPA standards for UMTRA Surface Project . . . . . . . . . . . . 2-2

2.2 UMTRA Surface Project scope baseline - incomplete sites . . . . . . . . 2-3

2.3 UMTRA Surface Project scope baseline - complete sites . . . . . . . . . 2-5

2.4 UMTRA Surface Project total project cost FY96 field budget . . . . . . . . . 2-8

2.5 UMTRA Project schedules . . . . . . . . . . . . . . . . . 2-11

3.1 UMTRA Surface Project responsibility/accountability assignment matrix $\ldots \ldots$. . 3-7

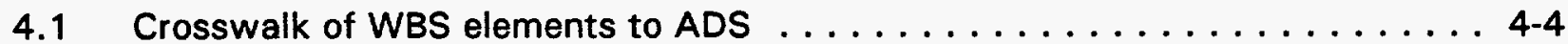

4.2 UMTRA Surface Project phases . . . . . . . . . . . . . . 4-6

5.1 Summary of UMTRA Surface Project thresholds $\ldots \ldots \ldots \ldots \ldots \ldots \ldots$

6.1 UMTRA Surface Project planning and management documents . . . . . . . 6-2

6.2 UMTRA Surface Project status and review meetings . . . . . . . . . . . 6-3

6.3 Project Office internal reports . . . . . . . . . . . . . . . . . 6-4

6.4 Project office external reports . . . . . . . . . . . . . . . . 6-6 


\title{
LIST OF ACRONYMS AND ABBREVIATIONS
}

\author{
Acronym \\ ADS \\ BIA \\ BLM \\ CADSAR \\ CCB \\ CEO \\ COR \\ DOE \\ DOE-AL \\ DOI \\ DOT \\ EAC \\ EH \\ EM \\ $E M-40$ \\ EPA \\ ESAAB \\ ES\&H \\ FTE \\ FY \\ HO \\ GJPO \\ IPMS \\ ISC \\ JEG \\ LTSM \\ LTSP \\ MK-F \\ MOU \\ MP \\ MSA \\ NEPA \\ NRC \\ OEPM \\ OGC \\ OMB \\ ORNL \\ PID \\ PLCC \\ PMPR \\ PMT \\ PTS

\section{Definition} \\ activity data sheet \\ Bureau of Indian Affairs \\ Bureau of Land Management \\ comparative analysis of disposal site alternatives report \\ Change Control Board \\ Council on Environmental Quality \\ contracting officer representative \\ U.S. Department of Energy \\ Albuquerque Operations Office \\ Department of the Interior \\ Department of Transportation \\ estimate at completion \\ Office of Environment, Safety and Health \\ Office of Environmental Restoration and Waste Management \\ Office of the Deputy Assistant Secretary for Environmental \\ Restoration \\ U.S. Environmental Protection Agency \\ Energy Systems Acquisition Advisory Board \\ environment, safety and health \\ full time equivalent \\ fiscal year \\ headquarters \\ Grand Junction Projects Office \\ Integrated Project Management System \\ inclusion survey contractor \\ Jacobs Engineering Group Inc. \\ long-term surveillance and maintenance \\ long-term surveillance plan \\ MK-Ferguson Company \\ memorandum of understanding \\ major project \\ major system acquisition \\ National Environmental Policy Act \\ U.S. Nuclear Regulatory Commission \\ Office of Environment/Project Management \\ Office of General Council \\ Office of Management and Budget \\ Oak Ridge National Laboratory \\ program identification document \\ prelicensing custodial care \\ Project Manager's Progress Report \\ process management team \\ Project Tracking System
}




\section{LIST OF ACRONYMS AND ABBREVIATIONS (Concluded)}

Acronym

PWBS

QA

QAPP

RAC

RAP

TAC

TEC

TPC

UMTRA

UMTRAP

UMTRCA

UPDCC

VP

WBS

\section{Definition}

Project work breakdown structure

quality assurance

quality assurance program plan

Remedial Action Contractor

remedial action plan

Technical Assistance Contractor

total estimated cost

total Project cost

Uranium Mill Tailings Remedial Action

Uranium Mill Tailings Remedial Action Program

Uranium Mill Tailings Radiation Control Act

UMTRA Document Control Center

vicinity property

work breakdown structure 


\subsection{INTRODUCTION}

\section{$1.1 \quad$ PROJECT PURPOSE}

The Uranium Mill Tailings Radiation Control Act (UMTRCA) of 1978 (42 USC $\$ 7901)$ authorizes the U.S. Department of Energy (DOE) to stabilize and control surface tailings and ground water contamination. To fulfill this mission, the DOE established two projects under the Uranium Mill Tailings Remedial Action (UMTRA) Project Office: the Surface Project and the Ground Water Project. The Ground Water Project was established in April 1991 as a major project (MP); a separate Project Management Plan will be prepared for that project. This document addresses the Surface Project (the "Project"), a major system acquisition (MSA).

Title I of the UMTRCA authorizes the DOE to undertake remedial action at 24 designated inactive uranium processing sites (Figure 1.1) and associated vicinity properties (VP) containing uranium mill tailings and related residual radioactive materials. The purpose of the UMTRA Surface Project is to minimize or eliminate radiation health hazards to the public and the environment at the 24 sites and related VPs.

\subsection{PROJECT SCOPE}

Pursuant to the UMTRCA, DOE remedial action shall be undertaken in cooperation with the affected states and Indian tribes and with the concurrence of the U.S. Nuclear Regulatory Commission (NRC). Remedial action shall be performed in accordance with standards promulgated by the U.S. Environmental Protection Agency (EPA) (40 CFR Part 192 (1994)), the NRC general license (10 CFR Part 40 (1994)), and applicable federal and state laws. Before remedial action is initiated at each site, the DOE must complete the environmental analyses, site-specific documentation, and public reviews required by the National Environmental Policy Act (NEPA) (10 CFR Part 1021 (1994)).

The UMTRCA authorizes the DOE to establish cooperative agreements with affected states and Indian tribes. The DOE is responsible for 100 percent of the assessment costs and 90 percent of the remediation costs. The affected states are responsible for the remaining 10 percent of the remediation costs, unless the site is on Indian lands. The DOE pays 100 percent of all costs at sites on Indian lands.

The UMTRCA also authorizes the cleanup of properties in the vicinity of the processing sites that are contaminated with radioactive materials from these sites. An estimated 8155 VPs show some evidence of such contamination and have been designated (identified through baseline surveys) as contaminated to some degree and consequently are candidates for inclusion in the Surface Project. "Included" properties (both designated and undesignated) are contaminated with residual radioactive contamination in excess of EPA 


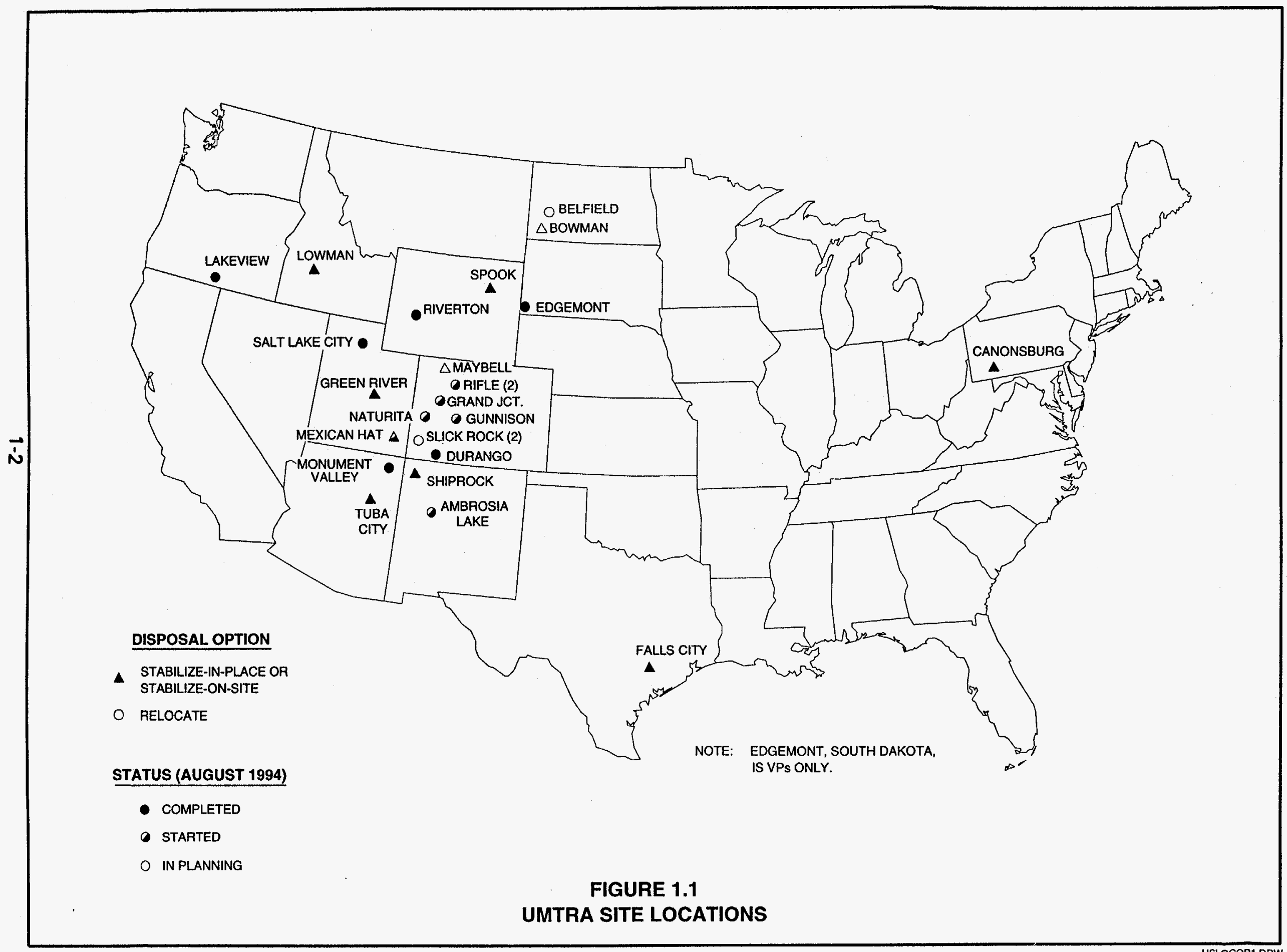


standards and are therefore eligible for cleanup. Surface Project plans, schedules, and cost estimates indicate inclusion of 5213 VPs for remedial action.

This document describes the management organization, system, and methods used to manage the design, construction, and other activities required to clean up the designated sites and associated VPs, in accordance with the UMTRCA.

This plan was prepared in accordance with the guidelines established in DOE Order 4700.1. Project Management System. It was developed within the context of the Project Charter (DOE, 1986), the UMTRA Surface Project Plan (DOE, 1993a), and other pertinent UMTRA Project documents. Reviewed and revised as necessary, these Project documents provide the basis for orderly and systematic planning and management. 


\subsection{OBJECTIVES}

\section{TECHNICAL OBJECTIVES}

Described in the Project Plan, the technical objectives of the Project are based on UMTRCA, proposed EPA standards, and NEPA requirements. The objective of the Projects remedial action is to stabilize and control the uranium mill tailings and other residual radioactive materials in compliance with the EPA's promulgated and proposed standards. These standards are the primary performance criteria governing the remedial action and they provide the basis for remedial action planning, scheduling, and cost estimating. Table 2.1 summarizes the EPA standards applicable to the UMTRA Surface Project. Tables 2.2 and 2.3 list the technical objectives for each site, including sitespecific disposal options, the ground water standards followed, and the amount of material and number of VPs associated with each site.

At some sites, (for example, vicinity properties) supplemental standards to the proposed EPA standards may be applied. The application of supplemental standards is permitted by 40 CFR $\$ 192.22(1994)$ and is detailed in the Vicinity Properties Management and Implementation Manual (DOE, 1994).

NEPA requires the Project to identify the potential environmental impacts of a proposed remedial action at each site before cleanup begins. The Council on Environmental Quality (CEQ) has the authority to make decisions on proposed remedial action and to implement NEPA procedural provisions (10 CFR Part 1021 (1994); 40 CFR Parts 1500 through 1508 (1994)). The CEQ regulations prescribe the steps by which NEPA goals are incorporated into the Project process.

After all remedial action is complete at a site and the site is certified by the NRC, the long-term surveillance plan (LTSP) for the disposal site may be finalized. When the NRC approves the LTSP, a site-specific NRC general license goes into effect and responsibility for the site transfers to the long-term surveillance and maintenance (LTSM) project, which is managed by the Grand Junction Projects Office (GJPO). The UMTRA Project Office retains responsibility for the site between certification of the remediated site and transfer of the licensed site to the GJPO. The UMTRA Project Office will maintain the site (or provide prelicensing custodial care) until the site is officially transferred to the GJPO. Sites licensed in fiscal year (FY) 1994 and FY1995 will be transferred to the GJPO within two months after licensing. Sites licensed in FY1996 and FY1997 will transfer to the GJPO by the end of FY1998.

\subsection{COST OBJECTIVES}

The Project cost objective is to complete remedial action within the total project cost (TPC) of $\$ 1471.6$ million, as presented in the FY1996 field budget. The 
Table 2.1 Summary of EPA standards for UMTRA Surface Project

\begin{tabular}{|c|c|}
\hline Activity & Standard \\
\hline Control of tailings piles & Control must be designed \\
\hline Longevity & - to be effective up to 1000 years but not less than 200 years. \\
\hline Radon emission & $\begin{array}{l}\text { not to exceed average release rate of } 20 \mathrm{pCi} \text { per square meter } \\
\text { per second OR not increase the annual average concentration } \\
\text { by more than } 0.5 \mathrm{pCi} \text { per liter }\end{array}$ \\
\hline Ground Water protection & $\begin{array}{l}\text { to meet } 1987 \text { proposed standards revised in } 1990 \text { (under EPA } \\
\text { review). }\end{array}$ \\
\hline Cleanup of buildings & - \\
\hline Indoor radon decay products & $\begin{array}{l}\text { Concentration caused by tailings must not exceed } 0.03 \text { working } \\
\text { level; however, the objective is that concentration caused by } \\
\text { tailings does not exceed } 0.02 \text { working level. }\end{array}$ \\
\hline Indoor gamma protection & $\begin{array}{l}\text { Not to exceed background level by more than } 20 \text { microroentgens } \\
\text { per hour }\end{array}$ \\
\hline Cleanup of land contamination & $\begin{array}{l}\text { Radium- } 226 \text { concentration in soil averaged over any area of } 100 \text { square } \\
\text { meters shall not exceed background by more than }\end{array}$ \\
\hline Surface & $\begin{array}{l}5 \text { pCi per gram, averaged over the first } 15 \mathrm{~cm} \text { of soil below the } \\
\text { surface. }\end{array}$ \\
\hline Buried & $\begin{array}{l}-15 \mathrm{pCi} \text { per gram averaged over } 15-\mathrm{cm} \text { thick layers more than } \\
15 \mathrm{~cm} \text { below the surface. }\end{array}$ \\
\hline
\end{tabular}

pCi - picocuries.

cm - centimeter. 


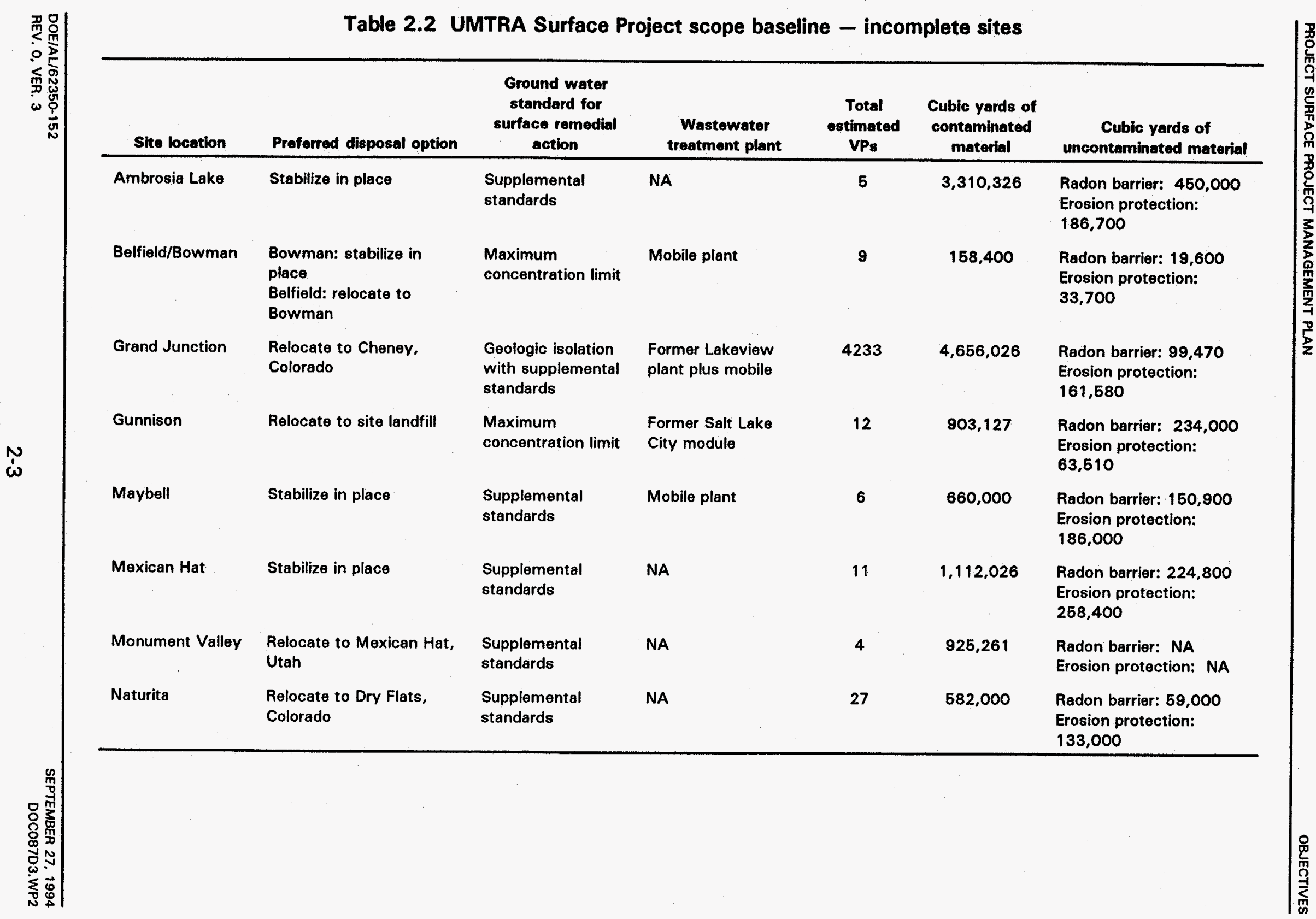




\begin{tabular}{|c|c|c|c|c|c|c|}
\hline Site location & Preferred disposal option & $\begin{array}{l}\text { Ground water } \\
\text { standard for } \\
\text { surface remedial } \\
\text { action }\end{array}$ & $\begin{array}{l}\text { Wastewater } \\
\text { treatment plant }\end{array}$ & $\begin{array}{l}\text { Total } \\
\text { estimated } \\
\text { VPs }\end{array}$ & $\begin{array}{l}\text { Cubic yards of } \\
\text { contaminatod } \\
\text { material }\end{array}$ & $\begin{array}{c}\text { Cubic yords of } \\
\text { uncontaminated material }\end{array}$ \\
\hline $\begin{array}{l}\text { Rifle } 12 \text { sites - } \\
\text { Old and New } \\
\text { Rifle) }\end{array}$ & $\begin{array}{l}\text { Relocate to Estes Gulch, } \\
\text { Colorado }\end{array}$ & $\begin{array}{l}\text { Geologic isolation } \\
\text { with supplemental } \\
\text { standards }\end{array}$ & $\begin{array}{l}\text { Former Salt Lake } \\
\text { City module }\end{array}$ & 104 & $4,057,000$ & $\begin{array}{l}\text { Radon barrier: } 836,000 \\
\text { Erosion protection: } \\
283,900\end{array}$ \\
\hline $\begin{array}{l}\text { Slick Rock } \\
(2 \text { sites - Umetco } \\
\text { and North } \\
\text { Continent Mines, } \\
\text { Inc.) }\end{array}$ & $\begin{array}{l}\text { Relocate to Burro } \\
\text { Canyon, Colorado }\end{array}$ & $\begin{array}{l}\text { Geological } \\
\text { isolation with } \\
\text { supplemental } \\
\text { standards }\end{array}$ & NA & 4 & 650,200 & $\begin{array}{l}\text { Radon barrier: } \mathbf{8 9 , 9 0 0} \\
\text { Erosion protection: } \\
48,100\end{array}$ \\
\hline
\end{tabular}

NA - not applicable.

Note: Data are for sites incomplete as of May 1994. 


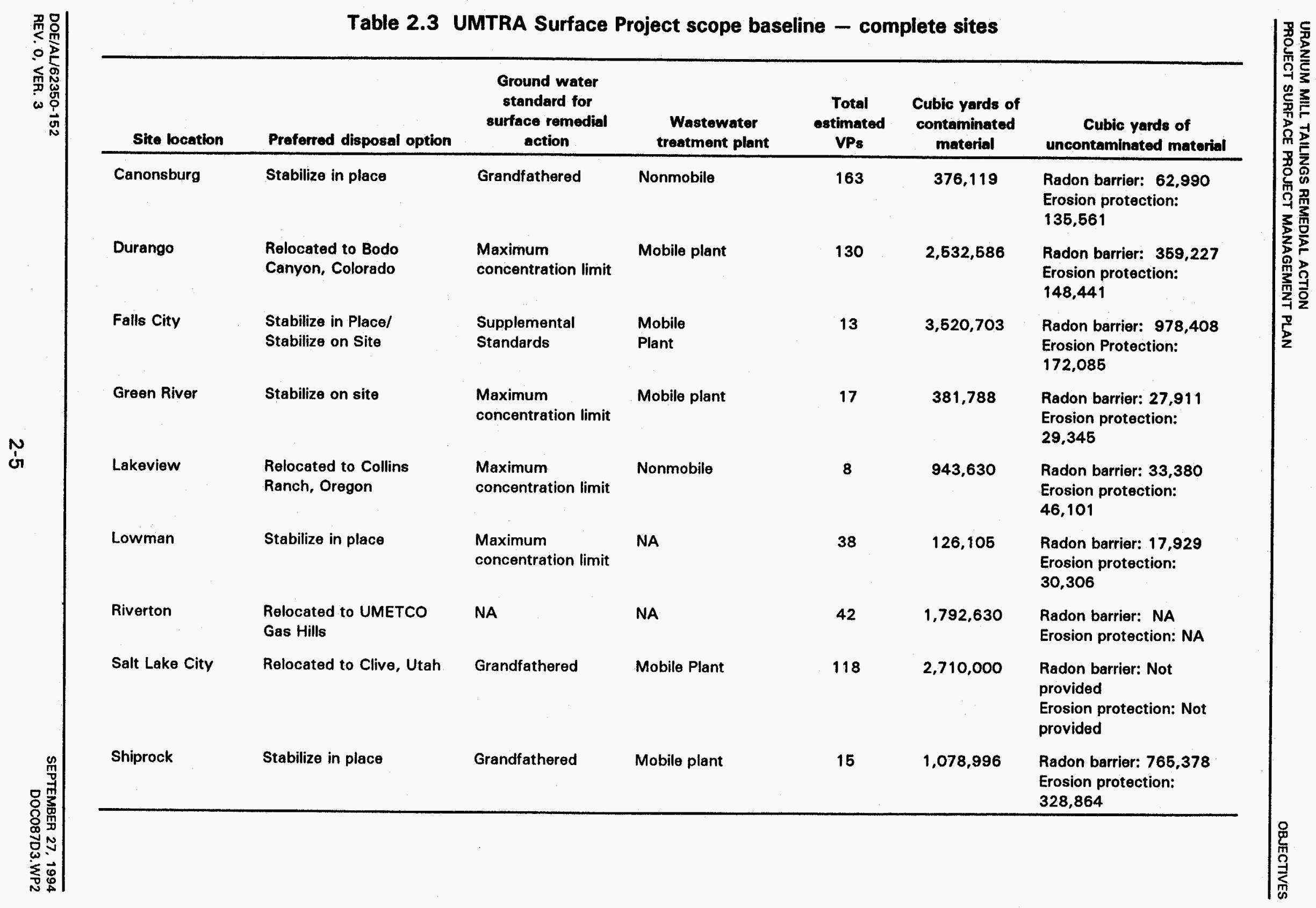




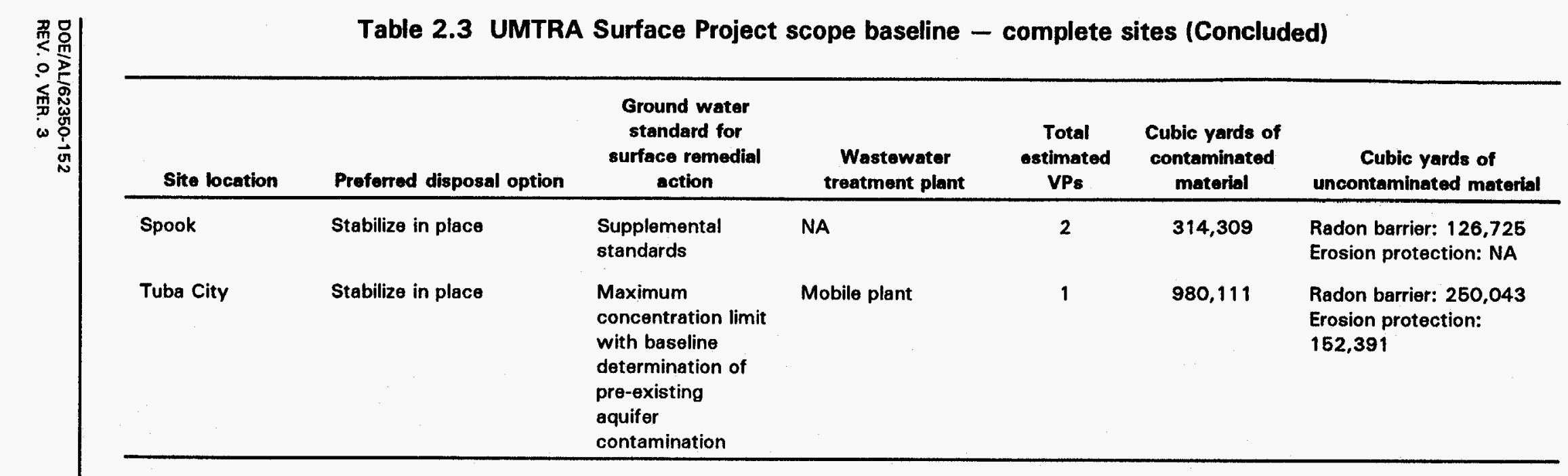

NA - not applicable.

Note: Data are for sites complete as of May 1994. 
TPC includes the states' share of remedial action costs. Remedial action costs are defined as engineering design and construction costs for processing sites, VP remedial action, and land-acquisition costs (except for sites on Indian land). Table 2.4 shows Project TPC at the third, or summary subproject, level of the work breakdown structure (WBS) shown in Figure 4.2.

\subsection{SCHEDULE OBJECTIVES}

The Project schedule objective is to complete all activities, including NRC licensing and transfer to the LTSM project, by the end of FY 1998 for all sites except Grand Junction. Grand Junction is scheduled for transfer to the LTSM project in FY1999 (Figure 2.1)

Meeting the schedule objectives is contingent upon the following, important factors:

- Timely authorization and appropriation of funds by Congress and the states in accordance with the project baseline resources plan (Figure 2.2).

- Timely completion and approval of NEPA documentation requirements.

- Concurrence on the part of the states, Indian tribes, and NRC

- No significant change in the quantity or complexity of the material scheduled for remediation.

The schedule contains the Project Office plan elements, decision points, and milestones required to accomplish the work by September 1998. The Project Office ensures all Project work is planned and scheduled to meet critical needs dates, coordinates effort among Project participants, and ensures the schedule provides visibility of work in progress, thereby providing the Project Office the information it needs to make timely management decisions on future courses of action.

Table 2.5 summarizes the UMTRA Surface Project schedules. 
Table 2.4 UMTRA Surface Project total project cost FY96 field budget

\begin{tabular}{|l|c|c|c|c|c|c|c|c|}
\hline \multirow{2}{*}{ Summary Subproject } & \multicolumn{9}{|c|}{ Total funding requirements (\$M) } \\
\cline { 2 - 11 } & Prior year funding & FY94 & FY95 & FY96 & FY97 & FY98 & FY99 & Total \\
\hline \hline Remedial Action & 906.9 & 55.1 & 86.4 & 58.5 & 28.2 & 17.0 & 1.2 & 1153.3 \\
\hline Surveillance and Maintenance & 5.1 & .6 & .8 & 1.3 & 1.3 & .5 & .2 & 9.8 \\
\hline Program Management Support & 231.9 & 13.1 & 14.9 & 25.9 & 9.8 & 8.2 & 4.7 & 308.5 \\
\hline Total Project Cost & 1143.9 & 68.8 & 102.1 & 85.7 & 39.3 & 25.7 & 6.1 & 1471.1 \\
\hline State share & $<76.6>$ & $<4.9>$ & $<8.2>$ & $<5.7>$ & $<2.7>$ & $<1.7>$ & $<.1>$ & $<99.5>$ \\
\hline Total Federal funding & 1067.3 & 64.3 & 93.9 & 80.0 & 36.6 & 24.0 & 6.0 & 1372.1 \\
\hline
\end{tabular}

ascalation rates based on the DOE "Departmental Price Change Index/Anticipated Economic Escalation Rates" for defense programs, EM, and

general construction, August 1993. 


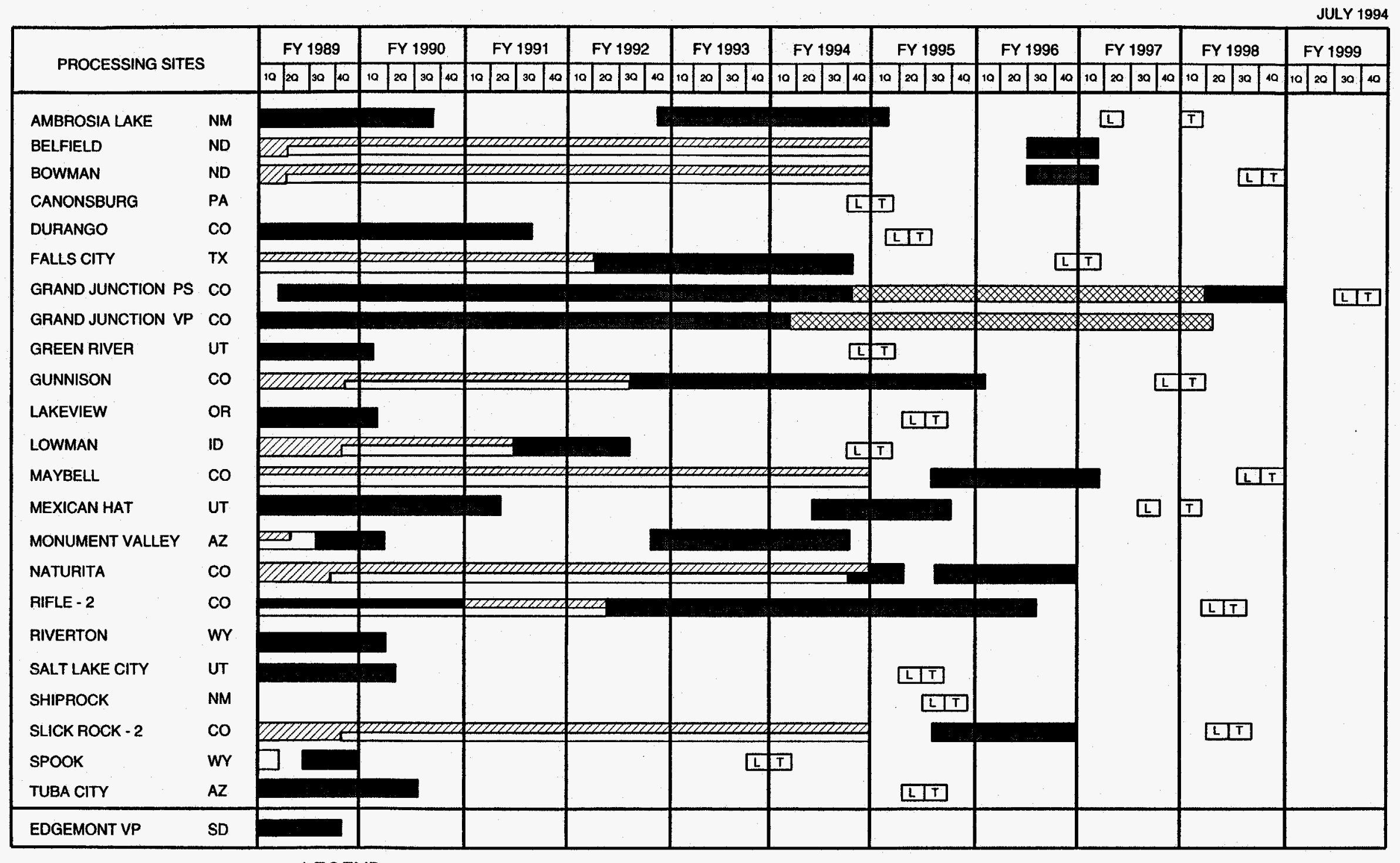

LEGEND

EZZZZD PLANNING \& DESIGN, NEPA REMEDIAL ACTION ENGINEERING

GRAND JUNCTION CELL CLOSURE EXTENSION $\square$ NRC LICENSE

TT TRANSFER TO GJPO LTSP
NOTE: VP REMEDIAL ACTION INCLUDED IN PROCESSING SITES, EXCEPT FOR FOR GRAND JUNCTION, RIFLE, AND FALLS CITY.

FIGURE 2.1

UMTRA SURFACE PROJECT SCHEDULE FY96 BUDGET SUBMITTAL 


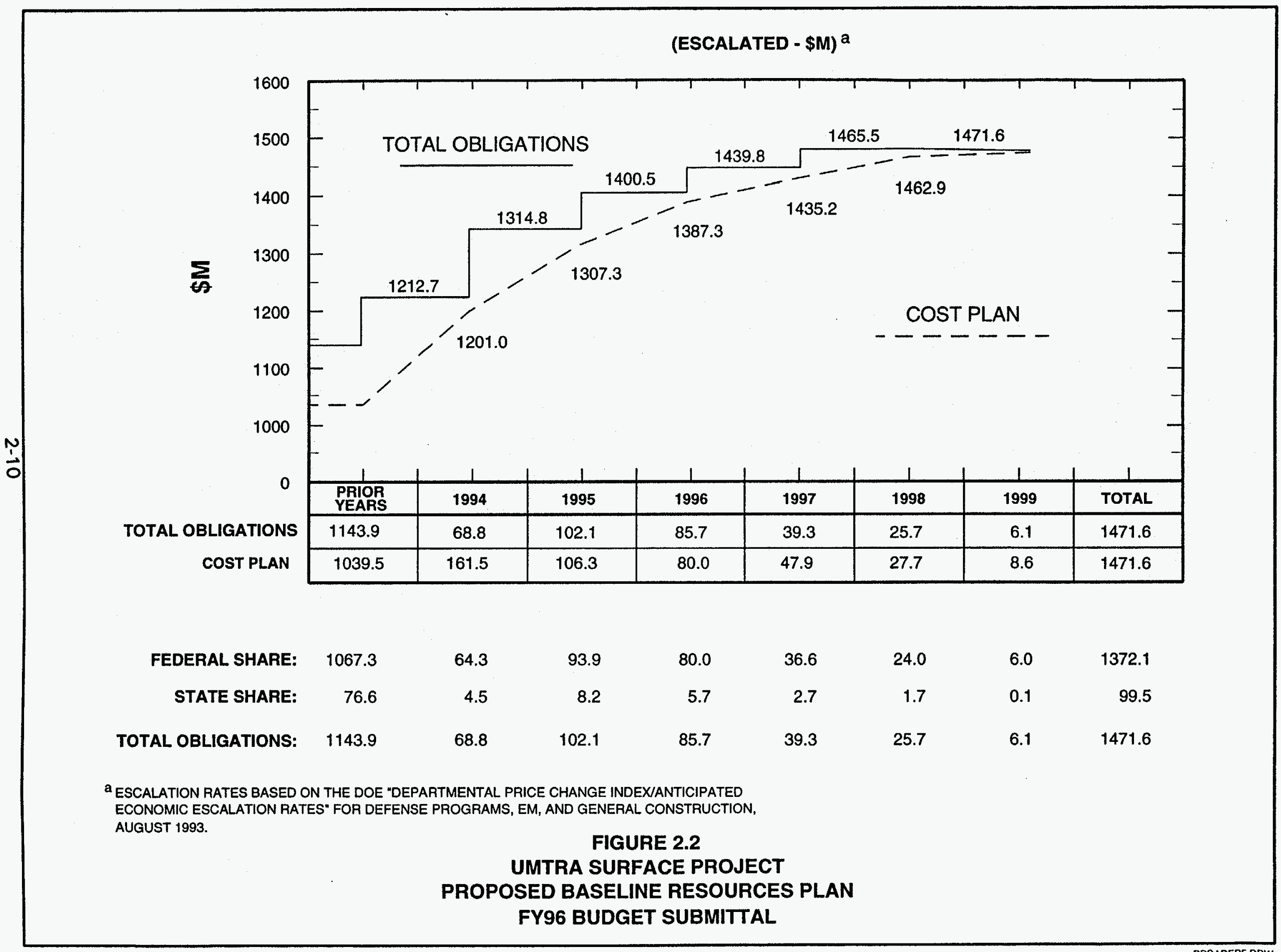


Table 2.5 UMTRA Project schedules

\begin{tabular}{|c|c|c|c|c|c|}
\hline $\begin{array}{l}\text { Schedule } \\
\text { level }\end{array}$ & Thle/format & Purpose & Input & Approved by & Updated \\
\hline 1 & $\begin{array}{l}\text { UMTRA Project master bar } \\
\text { chart }\end{array}$ & $\begin{array}{l}\text { Depicts critical PWBS }{ }^{\circ} \text { level } 2 \\
\text { elements }\end{array}$ & $\begin{array}{l}\text { HQ DOE/Project } \\
\text { Office }\end{array}$ & Project Office & Annually \\
\hline 2 & Critical path schedule & $\begin{array}{l}\text { Depicts the Project critical } \\
\text { path }\end{array}$ & $\begin{array}{l}\text { HQ DOE/Project } \\
\text { Office/contractors }\end{array}$ & Project Office & Monthly \\
\hline 2 & Site-specific detailed schedules & $\begin{array}{l}\text { Expands Project baseline by } \\
\text { site, establishes site working } \\
\text { schedule }\end{array}$ & $\begin{array}{l}\text { Project Officel } \\
\text { contractors }\end{array}$ & Project Otfice & Monthly \\
\hline 3 & IPMS $^{\mathbf{b}}$ schedule/tabular format & $\begin{array}{l}\text { Details site baseline and } \\
\text { working schedules }\end{array}$ & $\begin{array}{l}\text { Project Officel } \\
\text { contractors }\end{array}$ & $\begin{array}{l}\text { Project Officel } \\
\text { contractors }\end{array}$ & $\begin{array}{l}\text { Baseline: as required } \\
\text { Working: monthly }\end{array}$ \\
\hline 4 & $\begin{array}{l}\text { Contractor work } \\
\text { package/planning package } \\
\text { schedules/tabular format }\end{array}$ & $\begin{array}{l}\text { Further details the contractor } \\
\text { portion of the site baseline } \\
\text { and working schedules }\end{array}$ & Contractors & $\begin{array}{l}\text { Project Officel } \\
\text { contractors }\end{array}$ & $\begin{array}{l}\text { Baseline: as required } \\
\text { Working: monthly }\end{array}$ \\
\hline
\end{tabular}

Note: The Project baseline schedule and all site baseline schedules are revised based on approved Change Control Board activities (during the fiscal year) and annually (following fiscal-year appropriations).

QPWBS - Project work breakdown structure.

bIPMS - Integrated Project Management System. 


\subsection{MANAGEMENT ORGANIZATION AND RESPONSIBILITIES}

\subsection{PROJECT RESPONSIBILITIES}

The UMTRCA assigns responsibility for implementation of the UMTRA Project to DOE, states, tribes, and other federal agencies (Figure 3.1).

\subsection{DOE DECISION DELEGATIONS}

An established DOE process identifies DOE legislative functional support requirements. DOE responsibility for the UMTRA Project was assigned to the Assistant Secretary for Nuclear Energy. This responsibility was transferred to the Assistant Secretary for Environmental Restoration and Waste Management (EM) when EM was established; it is now the Assistant Secretary for Environmental Management. EM's programmatic responsibilities are assigned to the Office of Southwestern Area Programs and, in turn, to the Offsite Program Division, Mill Tailings Branch. The Project charter assigns day-to-day management responsibilities to the DOE Albuquerque Operations Office (DOE-AL). The charter also delineates the responsibilities and authorities of EM and DOE-AL and defines the terms and conditions for managing the UMTRA Project.

The Project Charter also defines the purpose of the Project, the mission of the DOE-AL Project Office, responsibilities and authorities of Headquarters organizations and the DOE-AL, reporting relationships, resources, and Project management control systems.

The DOE-AL has the authority to manage and execute Project activities within established procurement, real estate, and other operational approval thresholds. Responsibilities for the DOE-AL management of the Project are assigned through the Office of Environment/Project Management (OEPM) to the UMTRA Project Manager. The Project Manager is supported by the Project Office staff; DOE-AL staff matrix support; the DOE-AL GJPO, the TAC (Jacobs Engineering Group Inc. and its major subcontractors), the RAC (MK-Ferguson Co. and RUSTGeotech), the ISC (Oak Ridge National Laboratory), and other selected support contractors. The UMTRA Project Office is directly responsible for managing the Project and its contractors in accordance with DOE Headquarter's policies and guidance.

Specifically, the Project Office has the following responsibilities:

- Managing the NEPA compliance process.

- Developing disposal and stabilization technology for uranium mill tailings.

- Managing the selection and implementation of remedial action activities. 


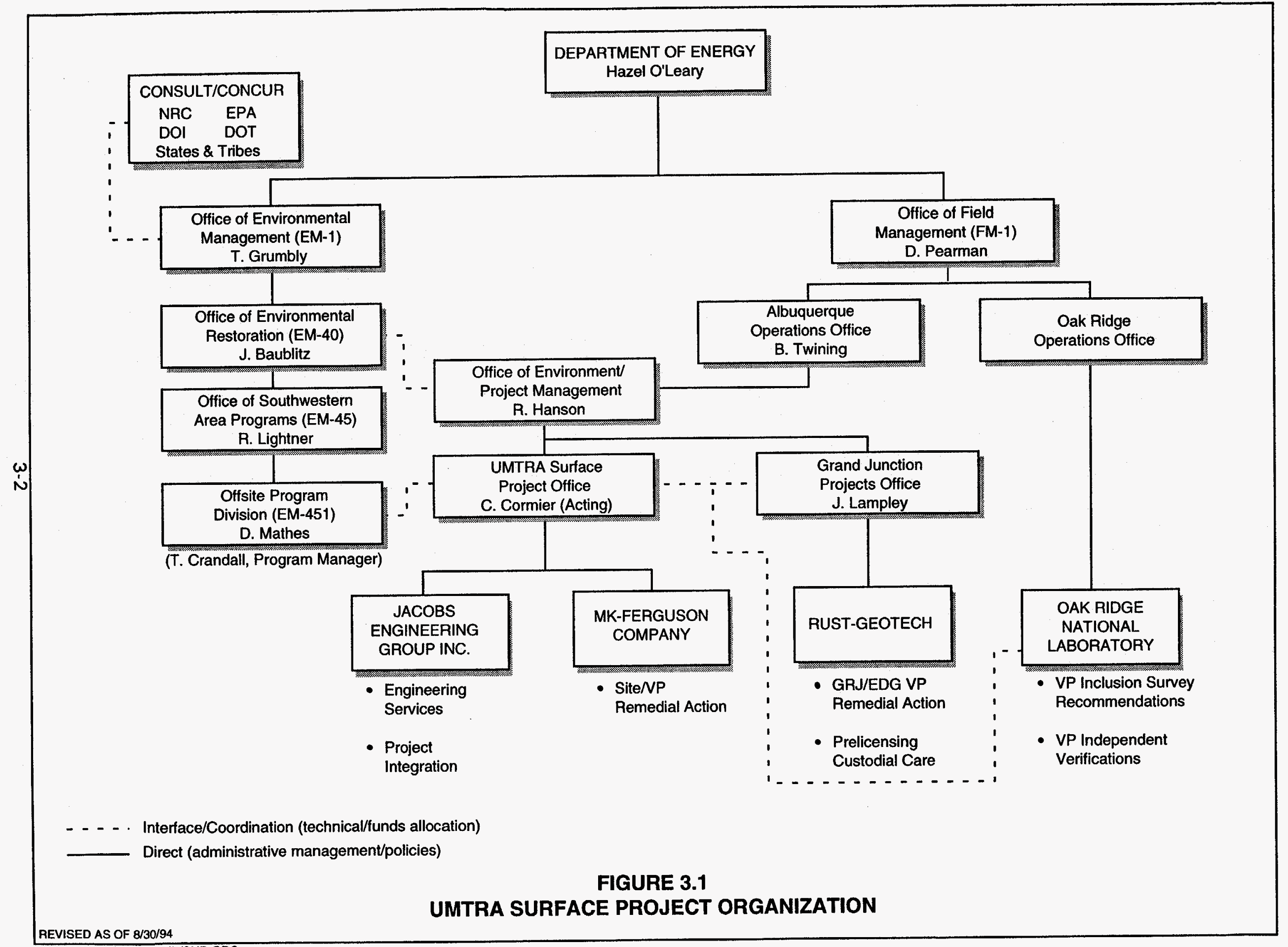


- Coordinating activities with Indian tribes, state and local governments, and the public.

- Negotiating cooperative agreements.

- Operating the Project Control System (PCS).

- Procuring Project contractors.

- Acquiring necessary licenses and permits.

- Operating the prelicensing custodial care program, pending turnover of site to the GJPO.

- Complying with regulations and orders.

The DOE-AL and Headquarters matrix support the Project Office in meeting these responsibilities in the areas of procurement, public affairs, quality assurance, property management, legal, health and safety, safeguards and security, and finance and budget.

\subsection{OTHER DOE SUPPORT}

\subsubsection{Office of General Council}

The Office of General Council (OGC) provides program legal assistance supporting implementation of the UMTRCA, provides legal advice and counsel on legally applicable or relevant and appropriate environmental standards, prepares model cooperative agreements, renews NEPA documents, and drafts memoranda of understanding between the DOE and other federal agencies.

\subsubsection{Assistant Secretary for Environment, Safety, and Health}

The office of the Assistant Secretary for Environment, Safety, and Health (ES\&H) determines which NEPA documents are needed for each site and reviews environmental documents; provides guidance on implementing applicable, relevant, or appropriate environment standards; and provides occupational safety and environmental overview for the Project.

\subsection{OTHER FEDERAL AGENCIES}

\subsubsection{Nuclear Regulatory Commission}

The DOE has entered into a memorandum of understanding with the NRC. The memorandum delineates concurrence procedures and areas of cooperation between the DOE and NRC in the implementation of Title I of the UMTRCA. As the chief regulatory agency, the NRC has the following responsibilities: 
- Consult in the designation of sites and establishment of site boundaries.

- Issue an NRC license for the LTSM of disposal sites.

- Accept the disposal site LTSP and put the general license into effect.

Before licensing a site, NRC concurrence is required in the following decisions:

- Cooperative agreements with the states and Indian tribes.

- Land acquisition and disposal.

- Selection of remedial action option.

- Determination that remedial action at a processing site is complete.

\subsubsection{U.S. Environmental Protection Agency}

The EPA, in accordance with the UMTRCA, has proposed standards for remedial action at inactive uranium processing sites. The standards were published on January 5, 1983, and became effective on March 7, 1983. However, the standards dealing with ground water contamination were remanded in September 1985. Proposed standards were issued in September 1987 and a revision was proposed in 1990 . The 1983 standards and the proposed ground water standards, as revised in 1990, are the current working standards required by the UMTRCA.

\subsubsection{U.S. Department of the Interior}

The Bureau of Land Management (BLM) and the Bureau of Indian Affairs (B|A) of the DOI also have the following Project related responsibilities:

- Bureau of Land Management:

- Memoranda of Understanding between the BLM responsible district offices and DOE-AL authorized the DOE and its contractors and subcontractors to conduct baseline environmental investigations on certain federal lands in Colorado; these lands are administered by the BLM. The baseline environmental investigations are conducted in support of Project proposed remedial action alternatives for the Maybell, Naturita, Slick Rock, and Gunnison sites. Site-specific documents related to the proposed remedial action follow NEPA guidance.

- Consultation about the possible use of public lands for disposal sites.

- Review of NEPA documents when BLM land withdrawal occurs. 
- Bureau of Indian Affairs:

- Consultation concerning sites on Indian lands.

- Review of NEPA documents when Indian lands are involved.

\subsubsection{Other federal agencies}

The Department of Transportation (DOT) is responsible for providing requirements for transporting contaminated waste.

\section{$3.5 \quad$ STATES/TRIBES}

The UMTRCA authorizes the DOE to enter into cooperative agreements with affected states and tribes. Through these cooperative agreements, the affected states and tribes have the following responsibilities:

- Consulting on NEPA documentation.

- Encouraging public participation.

- Consulting on designation of VPs within their borders.

- Participating in the selection of remedial action options.

- Recommending alternative disposal sites.

- Concurring on site remedial action plans (RAP).

- Acquiring processing and disposal sites, as appropriate (states only).

- Providing 10 percent of the remedial action costs (states only).

Another agreement effective for the state of Colorado is the Statement of Principles and Directives for the Implementation of the UMTRA Project in the state of Colorado. This statement, consistent with the UMTRCA and the DOEColorado cooperative agreement, outlines the principles and directives for expediting implementation of the UMTRA Project at the nine Colorado sites.

\subsection{DOE PRIME CONTRACTORS}

The Project Office is supported by four primary contractors: a Technical Assistance Contractor (TAC), two Remedial Action Contractors (RAC), and an inclusion survey/verification contractor (ISC).

\subsubsection{Technical Assistance Contractor}

The TAC develops and implements site characterization; conducts off-site radon monitoring; monitors technology development; prepares NEPA documentation; 
develops site remedial action concepts; prepares site RAPs, conceptual designs, and design criteria; reviews site final designs; recommends certification of remedial action; coordinates site licensing; and conducts interim surveillance and maintenance activities at disposal sites. The TAC is responsible for development, implementation, and operation of Project-level programs for health and safety, quality assurance (QA), public participation, document control, and cost and schedule control and integration. Jacobs Engineering Group Inc., with the support of its major subcontractors (Roy F. Weston, Inc.; AGRA E\&E; and Geraghty and Miller), is the TAC.

\subsubsection{Remedial Action Contractors}

- RAC at the sites. The RAC responsibilities at the sites include detailed engineering, construction, and inspection activities. The RAC also is responsible for health and safety, radiation, and environmental monitoring efforts on the site. The RAC is supported by its major subcontractors (MKEngineering and Chem Nuclear Waste Management Federal Environmental Services Inc.), as well as local subcontractors. MK-Ferguson Company is the RAC for all sites except Salt Lake City, Utah. Per a cooperative agreement, the state of Utah is the RAC for the Salt Lake City processing site and the South Clive disposal site.

- RAC at the vicinity properties. National Lead of Ohio, and Ford, Bacon, and Davis, respectively, conducted initial VP remedial action at Canonsburg, Pennsylvania, and Salt Lake City, Utah. When MK-Ferguson Company joined the Project as the RAC, it assumed responsibility for VP remedial action work at all sites except Grand Junction, Colorado, and Edgemont, South Dakota. RUST-Geotech now manages remedial action at these sites under the direction of the GJPO. RUST-Geotech also provides prelicensing custodial care between completion of remedial action and licensing and transfer to the LTSM Program.

\subsubsection{Inclusion Survev/Verification Contractor}

As the ISC for the Surface Project, Oak Ridge National Laboratory (ORNL) evaluates each designated VP to determine its eligibility for inclusion in the UMTRA Project. This evaluation consists of radiological surveys or mobile radiation surveys on the site, with detailed evaluations of the baseline radiological information. ORNL also verifies that remediated VPs comply with the EPA standards.

\subsection{RESPONSIBILITYIACCOUNTABILITY MATRIX}

Table 3.1 is a responsibility/accountability matrix for state and federal agencies and contractors. 


\begin{tabular}{|c|c|c|c|c|c|c|}
\hline \multirow[b]{2}{*}{ Project Phase } & \multicolumn{4}{|c|}{ Accountable organization } & \multicolumn{2}{|c|}{$\begin{array}{l}\text { Responsible } \\
\text { organization }\end{array}$} \\
\hline & TAC & MK-Ferguson & GJPO/RUST-Geotech & ORNL & States & NRC/DOI \\
\hline NEPA process & $\mathrm{x}$ & & & & & \\
\hline $\begin{array}{l}\text { Remedial action } \\
\text { planning }\end{array}$ & $x$ & & $x^{a}$ & $x^{b}$ & & \\
\hline Site acquisition & $x^{f}$ & & & & $x$ & $x^{\theta}$ \\
\hline VP remedial action & & $x^{a}$ & $x^{a}$ & & & \\
\hline Remedial action design & & $x^{a}$ & $x^{a}$ & & & \\
\hline Site remedial action & & $x^{a}$ & & & & \\
\hline Certification & $x^{c}$ & & & & $x$ & $x$ \\
\hline Licensing & $x^{c}$ & & & & & $x$ \\
\hline $\begin{array}{l}\text { Surveillance and } \\
\text { maintenance }\end{array}$ & $x$ & & $x^{d}$ & & & \\
\hline
\end{tabular}

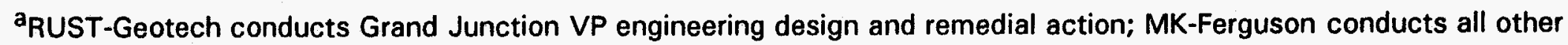
design and VP remedial action.

${ }^{b} V P$ inclusion/exclusion surveys.

${ }^{\mathrm{C}}$ Prepares documentation for NRC concurrence (includes LTSP).

dPrelicensing custodial care for all disposal sites.

eDOI, through BLM, withdraws public lands for disposal sites.

fProvides Real Estate support.

DOI - Department of the Interior 


\subsection{MANPOWER REQUIREMENTS}

Project Office staffing is phased to correspond to the scheduled accomplishment of the Project mission. As the site work moves toward completion in FY1998, staffing requirements will drop accordingly. Figure 3.2 presents the total Surface Project staffing plans in full time equivalents (FTE) for DOE and prime contractors. 


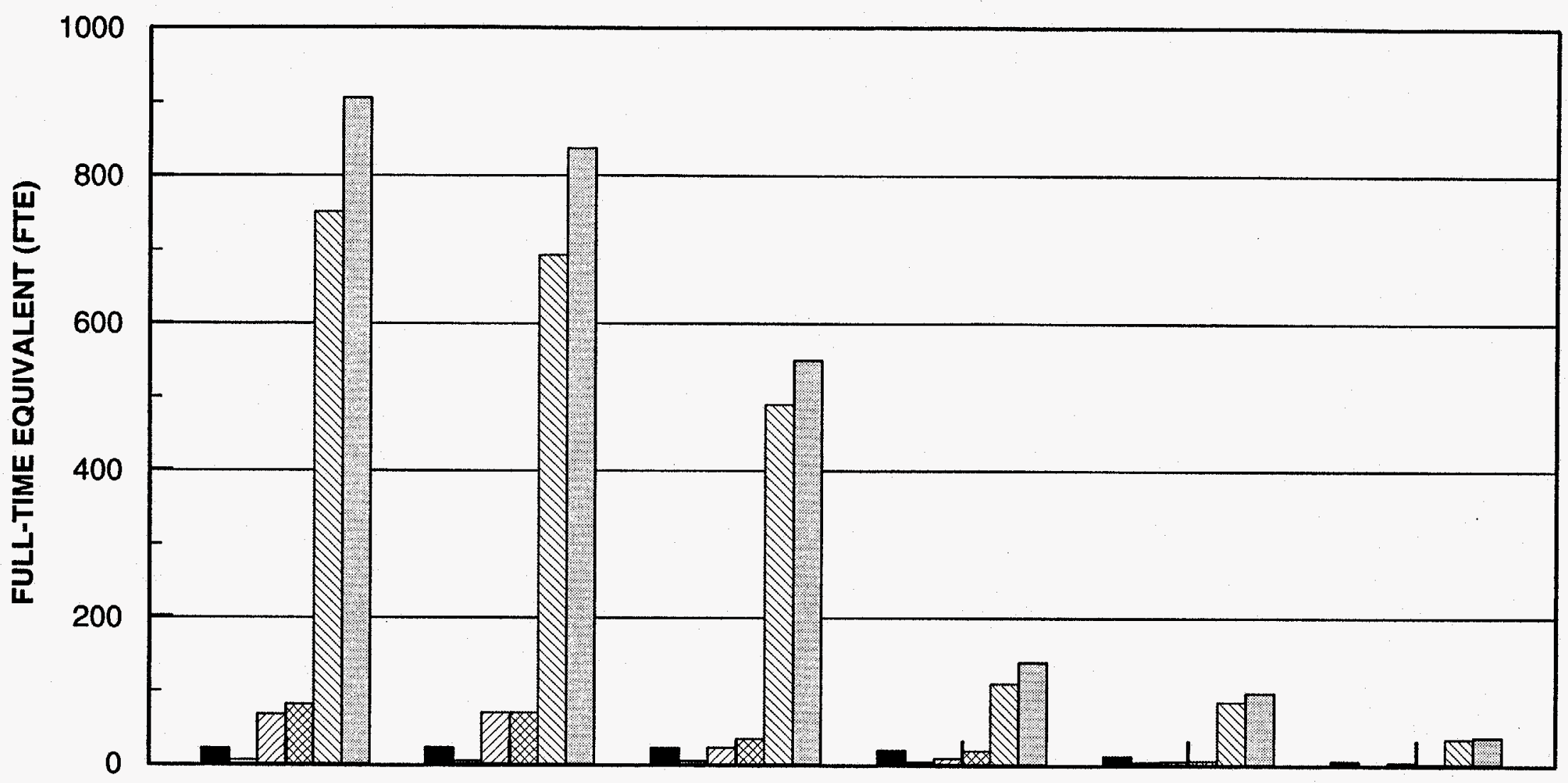

\begin{tabular}{|c|c|c|c|c|c|c|}
\hline PARTICIPANT FISCAL YEAR & 1994 & 1995 & 1996 & 1997 & 1998 & 1999 \\
\hline DOE & 21 & 22 & 22 & 19 & 11 & 4 \\
\hline ORNL & 5.3 & 4.3 & 3.8 & 3.4 & 2.8 & 0.0 \\
\hline EIIIIA & 67.6 & 70.1 & 22.1 & 7.8 & 4.4 & 1.8 \\
\hline 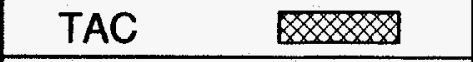 & 81.4 & 69.8 & 34.7 & 18.1 & 5.0 & 0.5 \\
\hline DIIIV & 750.5 & 692.1 & 489.2 & 109.7 & 84.7 & 34.1 \\
\hline TOTAL & 904.7 & 836.3 & 549.8 & 139.0 & 96.9 & 36.4 \\
\hline
\end{tabular}

FIGURE 3.2

UMTRA SURFACE PROJECT STAFFING PLANS

FY96 BUDGET SUBMITTAL 



\subsection{WORK PLAN}

\section{$4.1 \quad$ INTRODUCTION}

After the EPA standards were promulgated, generic processing site and vicinity property work plans were adopted and the first budgets and schedule estimates were developed. The Project planning is based on the Project work breakdown structure (PWBS).

\subsection{WORK BREAKDOWN STRUCTURE}

The UMTRA Surface PWBS, (Figure 4.1), is organized into work elements which promote completion of the Project work plan in a uniform and integrated manner. Level 1 represents the overall Project. Level 2 elements are the designated Project sites and an element for nonsite-specific activities for which Level 3 tasks are to be accomplished. Level 3 contains the major Project functional work elements. Level 4 contains the key PWBS elements for planning and control.

The Level 3 element Technical and Management Support is currently under revision by the Project Office. In this revision the Project Office seeks to provide more detail of the effort performed under this element. Once this revision is accomplished, a revised WBS will be incorporated into the next revision of this management plan document.

Figure 4.2 subdivides the Project work into activity data sheets (ADS). The ADSs are the primary budgeting and reporting documents for DOE EM activities. For budgeting and reporting, EM requires that project work be divided into three summary subprojects: remedial action, program management support, and surveillance and maintenance. To satisfy this requirement, the Project Office has identified the level 3 PWBS elements for each ADS. The crosswalk of PWBS elements to ADS categories is shown in Table 4.1.

\subsection{PROJECT PHASING}

The Project work plan follows the phases of an MSA: conceptual design, advanced development, final design, construction, and operations. The MSA process is driven by key decision milestones. Each key decision provides approval to advance to the next phase in the MSA process. Each Surface Project site progresses through the MSA process on its own schedule; therefore, sites are distributed through the MSA phases according to their individual work plans. The Project advances to the next key decision when the first site has completed the previous phase, except for key decision three which will be when the last site completes. Figure 4.3 shows how the UMTRA Project phases relate to the MSA phases and to key decision milestones. It also shows the phase of each site as of the publication of this document. Table 4.2 identifies 


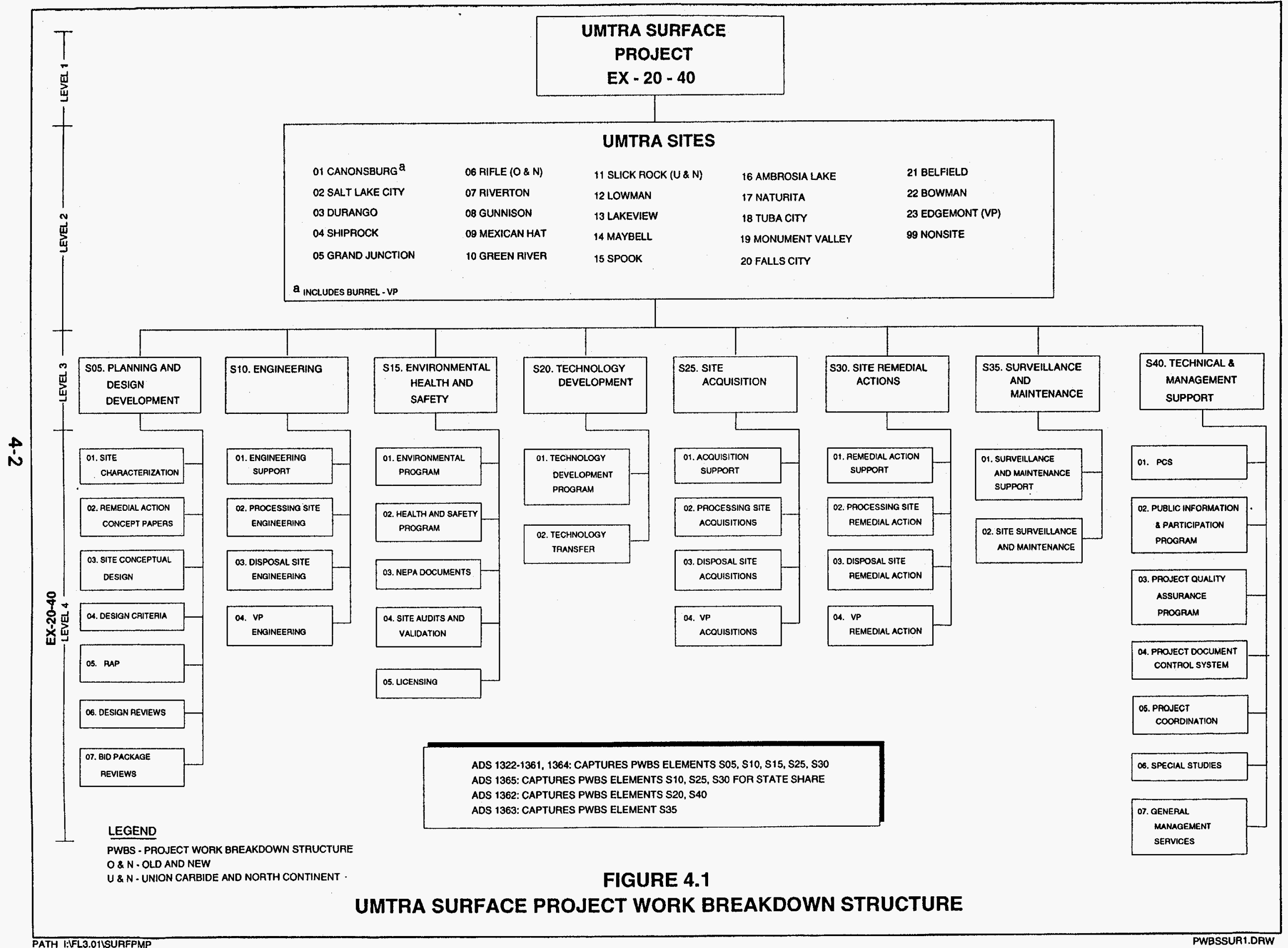




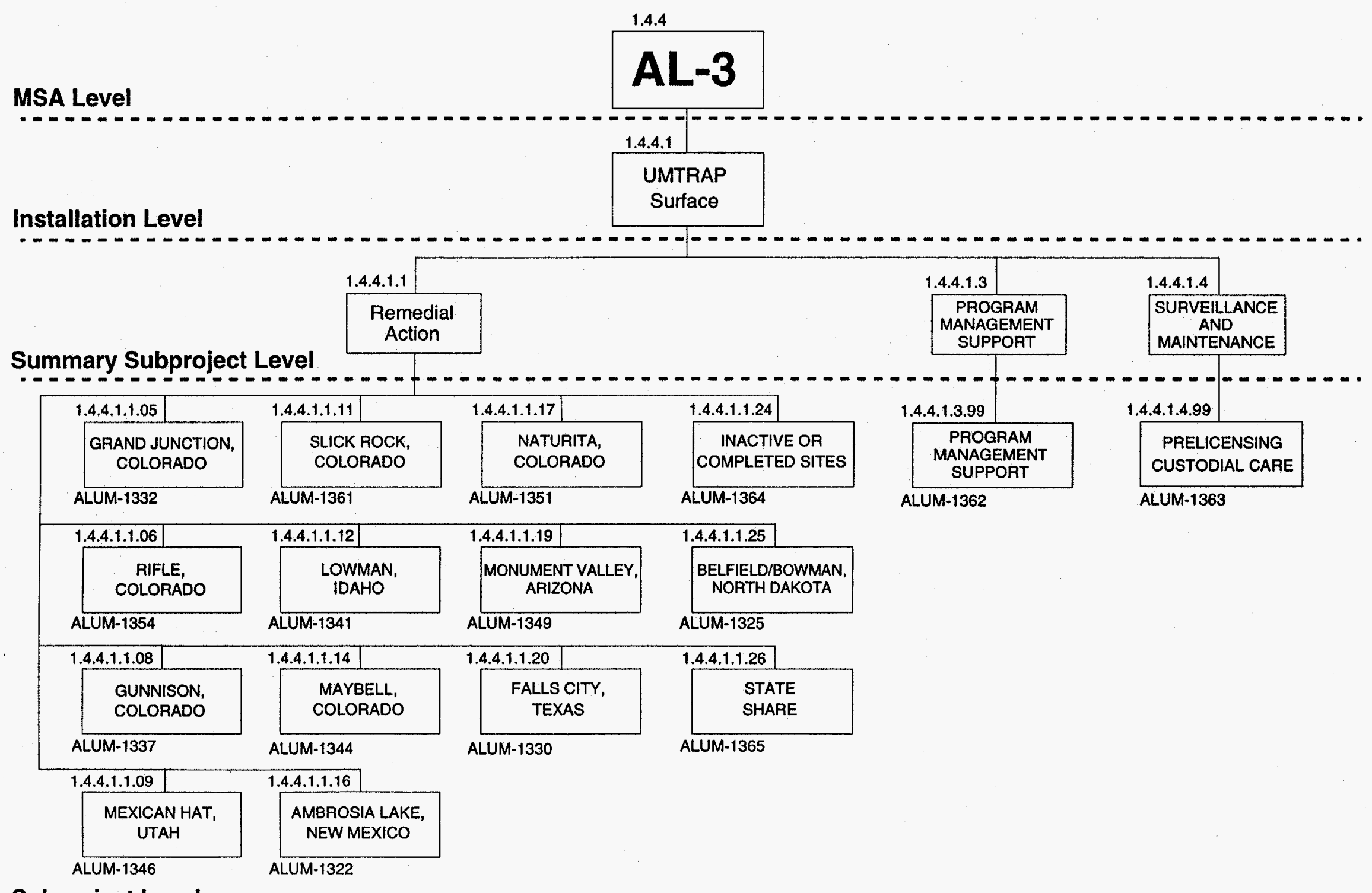

Subproject Level 
Table 4.1 Crosswalk of WBS elements to ADS

\begin{tabular}{lclc}
\hline \multicolumn{1}{c}{ Activity } & ADS & \multicolumn{1}{c}{ Site } & WBS element \\
\hline Site remedial action & 1322 & Ambrosia & $05 / 10 / 25 / 30$ \\
& 1325 & Belfield/Bowman & $05 / 10 / 25 / 30$ \\
& 1330 & Falls City & $05 / 10 / 25 / 30$ \\
& 1332 & Grand Junction & $05 / 10 / 25 / 30$ \\
& 1337 & Gunnison & $05 / 10 / 25 / 30$ \\
& 1344 & Maybell & $05 / 10 / 25 / 30$ \\
& 1346 & Mexican Hat & $05 / 10 / 25 / 30$ \\
& 1349 & Monument Valley & $05 / 10 / 25 / 30$ \\
Project management support & 1351 & Naturita & $05 / 10 / 25 / 30$ \\
Surveillance and maintenance & 1354 & Rifle & $05 / 10 / 25 / 30$ \\
Completed site remedial action & 1361 & Slick Rock & $05 / 10 / 25 / 30$ \\
State share & 1362 & All & $15 / 20 / 40$ \\
& 1363 & All & 35 \\
& 1364 & Completed sites & $05 / 10 / 25 / 30$ \\
& 1365 & All & $10 / 25 / 30$ \\
\hline
\end{tabular}

the activity, products, and decision required in each Project phase. The planning documents for work plan activities are listed in an attachment to this document.

The Project is currently in the construction phase of the MSA process; remedial action is completed at 11 sites. Key decision No. 1, Approval of New Start, confirmed the Project mission need; the acquisition executive approved the original Surface Project plan on August 2, 1983. Completion of the RAP for the first site (Canonsburg, Pennsylvania) was based on key decision No. 2, Approval to Commence Final Design. Key decision No. 3, Approval to Commence Construction, was based on completion of the detailed engineering design for the Canonsburg site. Bringing the last site under the NRC general license will be the basis for key decision No. 4, Approval to Commence Operation. After key decision No. 4, the Surface Project will terminate and responsibility for the disposal sites will transfer to the LTSM project, managed by the GJPO.

\subsection{LOGIC DIAGRAM}

Logic diagrams identify the critical path for each site's work plan. Figure 4.4 is a generic, functional site logic diagram based on the project master schedule. This diagram is used for generic illustration only because the site-specific detailed site diagrams are lengthy. 


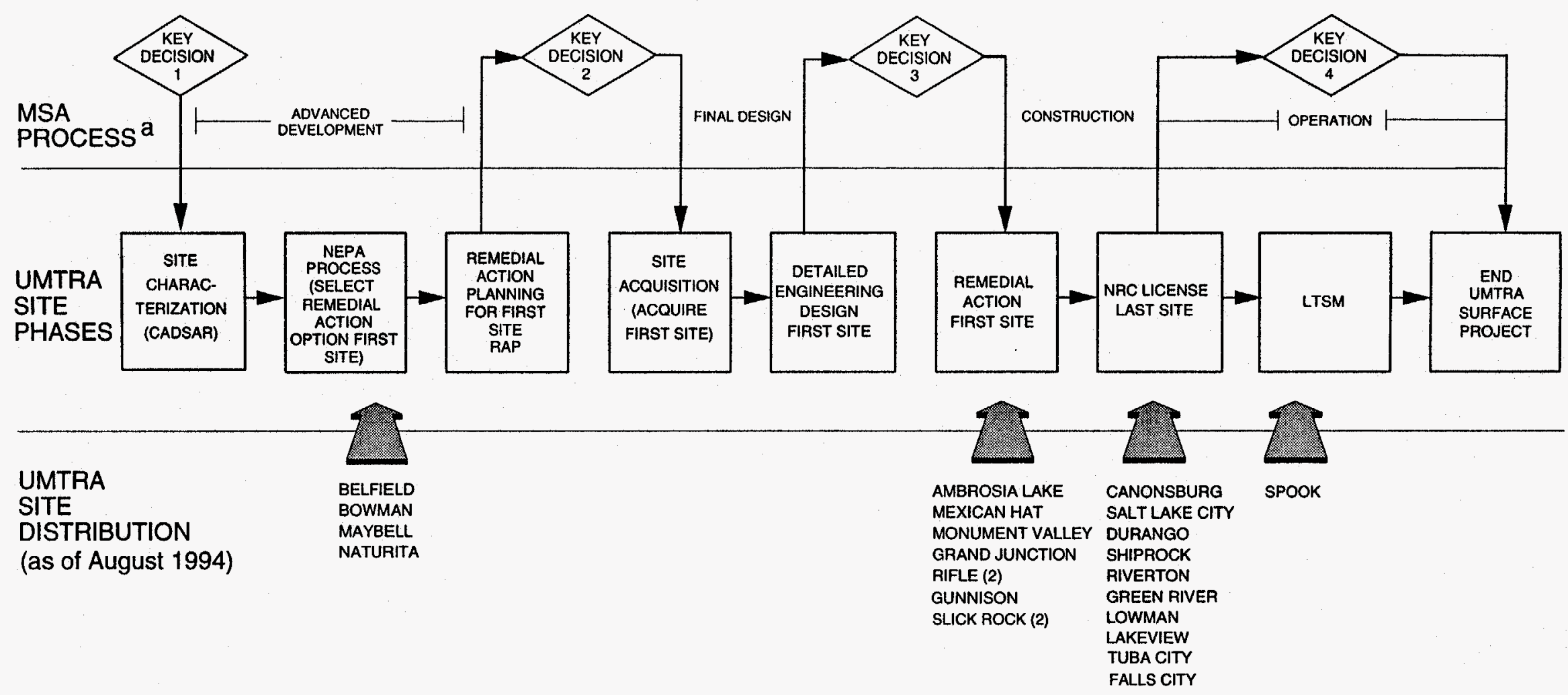

\section{LEGEND}

a KEY DECISION O DID NOT EXIST AT THE INCEPTION OF THIS PROJECT.

CADSAR - COMPARATIVE ANALYSIS OF DISPOSAL SITE ALTERNATIVES REPORT

FIGURE 4.3

UMTRA SURFACE PROJECT PHASES AND KEY DECISIONS 
Table 4.2 UMTRA Surface Project phases

\begin{tabular}{|c|c|c|c|c|}
\hline Project phase & Activity & Description & Product & Decision \\
\hline Site characterization & $\begin{array}{l}\text { Drilling bore holes and } \\
\text { evaluating extent of } \\
\text { contamination. }\end{array}$ & $\begin{array}{l}\text { Characterize the candidate } \\
\text { disposal sites to evaluate } \\
\text { their suitability for use. }\end{array}$ & $\begin{array}{l}\text { Comparative analysis of } \\
\text { disposal site alternatives } \\
\text { report }\end{array}$ & $\begin{array}{l}\text { Provide information used } \\
\text { in EA to support disposal } \\
\text { site selection. }\end{array}$ \\
\hline NEPA process & $\begin{array}{l}\text { Conduct environmental } \\
\text { assessment and develop } \\
\text { remedial action and } \\
\text { disposal options. }\end{array}$ & $\begin{array}{l}\text { Collect and analyze data. } \\
\text { Develop and evaluate options } \\
\text { for remedial action based on } \\
\text { analysis. }\end{array}$ & $\begin{array}{l}\text { Environmental assessment/ } \\
\text { FONSI/environmental } \\
\text { impact statement/ROD }\end{array}$ & $\begin{array}{l}\text { Determine remedial action } \\
\text { protocol. }\end{array}$ \\
\hline $\begin{array}{l}\text { Remedial action } \\
\text { planning }\end{array}$ & $\begin{array}{l}\text { Plan remedial action and } \\
\text { design development. }\end{array}$ & $\begin{array}{l}\text { Prepare detailed site plan for } \\
\text { remedial action. }\end{array}$ & Draft RAP & $\begin{array}{l}\text { Ensure that RAP meets } \\
\text { EPA standards and } \\
\text { requirements. Proceed } \\
\text { with engineering } \\
\text { development. }\end{array}$ \\
\hline Site acquisition & Acquire site. & $\begin{array}{l}\text { Purchase fee simple title, } \\
\text { withdraw land from public } \\
\text { domain, or access Indian } \\
\text { lands. }\end{array}$ & $\begin{array}{l}\text { Remedial action agreement, } \\
\text { real estate purchase } \\
\text { agreement, or land } \\
\text { withdrawal application }\end{array}$ & $\begin{array}{l}\text { Acquire land in time to } \\
\text { support remedial action } \\
\text { schedule. }\end{array}$ \\
\hline $\begin{array}{l}\text { Remedial action } \\
\text { design }\end{array}$ & $\begin{array}{l}\text { Conduct detailed } \\
\text { engineering. }\end{array}$ & $\begin{array}{l}\text { Prepare drawings, } \\
\text { specifications, cost estimate, } \\
\text { and schedule; finalize RAP. }\end{array}$ & Final RAP/final design & $\begin{array}{l}\text { Proceed into remedial } \\
\text { operations. }\end{array}$ \\
\hline Site remedial action & $\begin{array}{l}\text { Conduct remedial } \\
\text { operations. }\end{array}$ & $\begin{array}{l}\text { Implement remedial action } \\
\text { outlined in RAP. }\end{array}$ & $\begin{array}{l}\text { Stabilized site and site } \\
\text { completion report }\end{array}$ & $\begin{array}{l}\text { Remedial action complies } \\
\text { with EPA standards. }\end{array}$ \\
\hline $\begin{array}{l}\text { Certification/ } \\
\text { licensing }\end{array}$ & $\begin{array}{l}\text { Verify EPA standards are } \\
\text { met. Meet NRC } \\
\text { requirements for } \\
\text { disposal-site license. }\end{array}$ & $\begin{array}{l}\text { With NRC concurrence, } \\
\text { certify provisions of the final } \\
\text { design are satisfied; prepare } \\
\text { and submit site LTSP to } \\
\text { NRC. }\end{array}$ & $\begin{array}{l}\text { Certification report; general } \\
\text { license for post-remedial } \\
\text { maintenance }\end{array}$ & $\begin{array}{l}\text { Concurrence that } \\
\text { remedial action } \\
\text { conducted per final } \\
\text { design. Disposal site } \\
\text { integrity. }\end{array}$ \\
\hline $\begin{array}{l}\text { Long-term } \\
\text { surveillance and } \\
\text { maintenance }\end{array}$ & Implement monitoring. & $\begin{array}{l}\text { Inspect site to ensure it } \\
\text { remains environmentally } \\
\text { sound. }\end{array}$ & $\begin{array}{l}\text { Site inspection and annual } \\
\text { surveillance and } \\
\text { maintenance reports }\end{array}$ & $\begin{array}{l}\text { Begin long-term } \\
\text { surveillance and } \\
\text { maintenance. }\end{array}$ \\
\hline
\end{tabular}

FONSI - Finding of No Significant Impact.

ROD - record of decision.

Purchase fee simple title thdraw land from public omain, or access Indian

Prepare drawings, specifications, cost estimate, plement remedial action

With NRC concurrence, and submit site LTSP to

Inspect site to ensure it sound. 


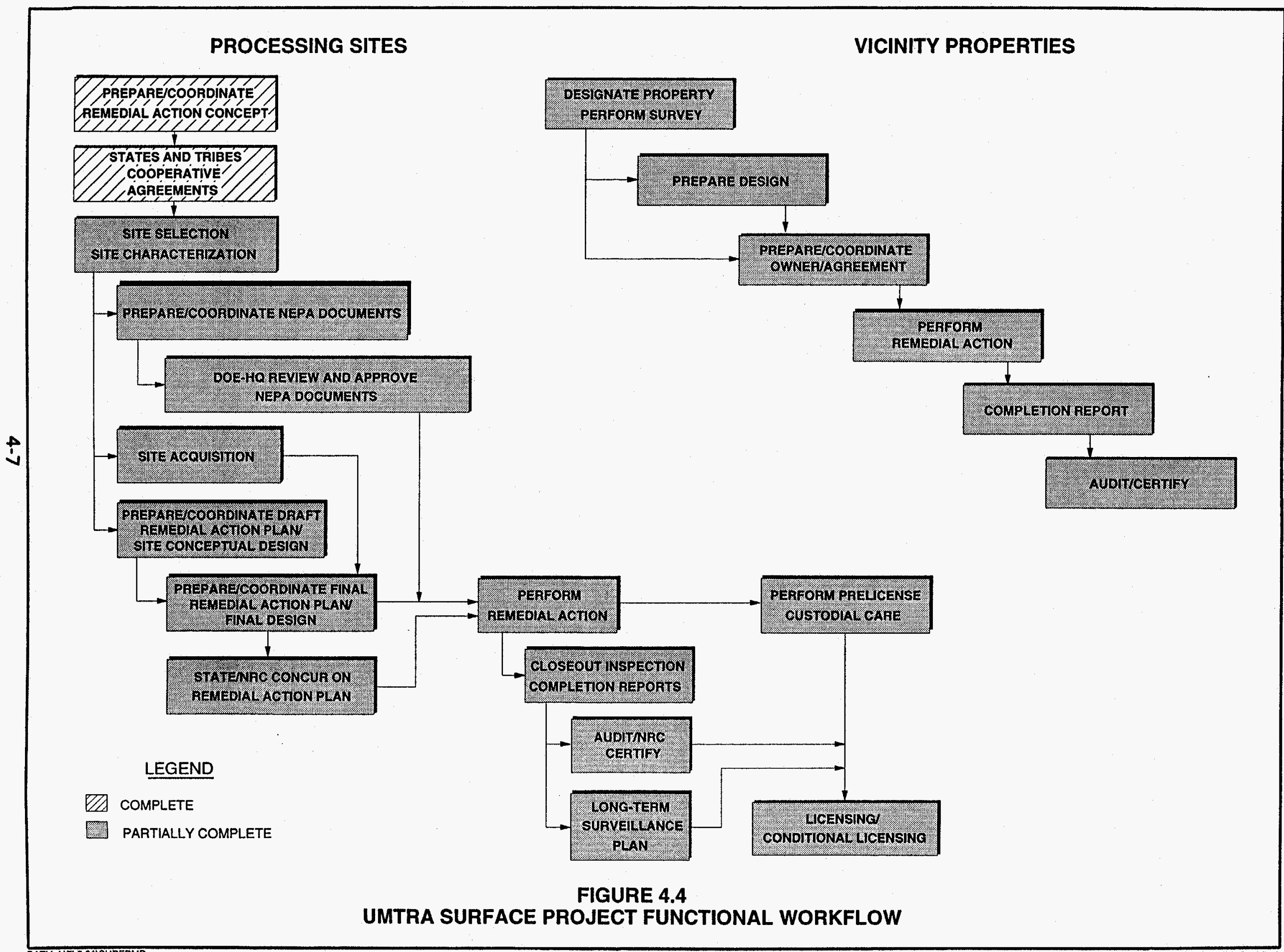




\subsection{PROJECT MANAGEMENT, MEASUREMENT, AND PLANNING AND CONTROL SYSTEMS}

\section{$5.1 \quad$ INTRODUCTION}

The Integrated Project Management System (IPMS) is designed to measure and report on the established Project cost, schedule, and technical baselines. Contractors establish supporting baselines based on a defined scope of work, schedule, and contract values. Contractor performance is reported to the Project Office, as specified in their contracts. Project performance is reported to DOE Headquarters (HO) with the automated Progress Tracking System (PTS) software.

The Project Office continually reviews in-place management and control systems to ensure the proper levels of control in each phase of the Project. The Integrated Project Management System Description (DOE, 1993b) is in revision to incorporate changes as a result of this continual review process and to be in compliance with DOE Order 4700.1 and DOE Notice 4700.5 .

\subsection{THE INTEGRATED PROJECT MANAGEMENT SYSTEM}

The IPMS uses a feedback control concept: a plan is established, performance is measured against the plan, and action is taken when plan and performance diverge significantly.

Each UMTRA Project prime contractor is required to implement Project management controls and contract reporting, consistent with contract value, duration, and degree of risk to the contract. Each contractor also is required to submit a Project management and control system description (describing the internal controls) to the Project Office for approval. After Project Office approval, the contractor implements the plan and submits updates to support Project Office budget and to reflect final fiscal year budget appropriations.

The DOE reviews and evaluates each contractor's management and control system through reports and observations on the site to verify the system operates as described. When a system is accepted, subsequent changes must be approved by the cognizant Project Office contracting officer representative (COR) and contracting officer before a change is implemented.

The Project Office and DOE-AL monitors each accepted project control system throughout the life of the contract by reviewing the contractor's monthly performance reports and by conducting on-site reviews of the system in operation. These reviews emphasize the preparation and maintenance of detailed work schedules, the methods for developing budgets, the consistency of performance measurement, and the status of the cost, schedule, and technical baselines with the approved Change Control Board (CCB) actions. If 
these reviews indicate potential system problems, the Project Manager directs the necessary corrective action through the appropriate channels.

\subsection{BASELINE CONTROL}

UMTRA Project cost, schedule, and technical baselines are documented and controlled at the Project, site, and contractor levels. Control thresholds for each cost, schedule, and technical baseline are established at each level of DOE management: the Acquisition Executive (Level 0), the Program (Level 1), and the Project/Field (Level 2), as depicted in Table 5.1. Performance is measured and evaluated by comparing performance to the baseline.

At the Project Office level (Level 2), the Project CCB overviews and integrates site activities and recommends changes to the Project baselines that exceed the predetermined change thresholds. The CCB is composed of Project Office voting members and contractor representatives. The CCB evaluates each CCB request that comes before it and approves, disapproves, tables, or recommends approval by the Project Manager, if required. The Project Manager has final approval on CCB requests that exceed $\$ 5$ million, create schedule changes of 6 months or more, originate with contractors not directly controlled by the Project Office, or require Program Office- or acquisition executive-level approval. However, the Project Manager has the prerogative to approve or disapprove all, or part, of any CCB decision at his discretion. Baselines are revised only after approval by the Project Manager, appropriate authorities, CCB, program office, or acquisition executive. The CCB procedures are an appendix to the Integrated Project Management System Description (DOE, 1993b).

\subsubsection{Cost Baseline Control}

The Project Office controls the cost baseline through TPC and site-specific cost management and by analyzing contractor-submitted reports. These reports highlight cost trends and evaluate contractor cost projections to determine their impact on the Project.

The Project Office evaluates contractor estimates at completion (EAC) to ensure they are based upon current schedules and authorized work that is consistent with the Project work plan. Project participants develop EACs from on the latest performance data; current assessment of changed conditions; current, realistic pricing factors and rates; and knowledgeable forecasts of future conditions. Each contractor includes EACs in a monthly status report to the Project Office.

\subsubsection{Schedule Baseline Control}

The following uniform schedule controls ensure all contractors and their subcontractors use similar methods to develop schedules and meet common Project objectives. Schedules are updated monthly and reflect the consensus of the Project Manager and site managers. 


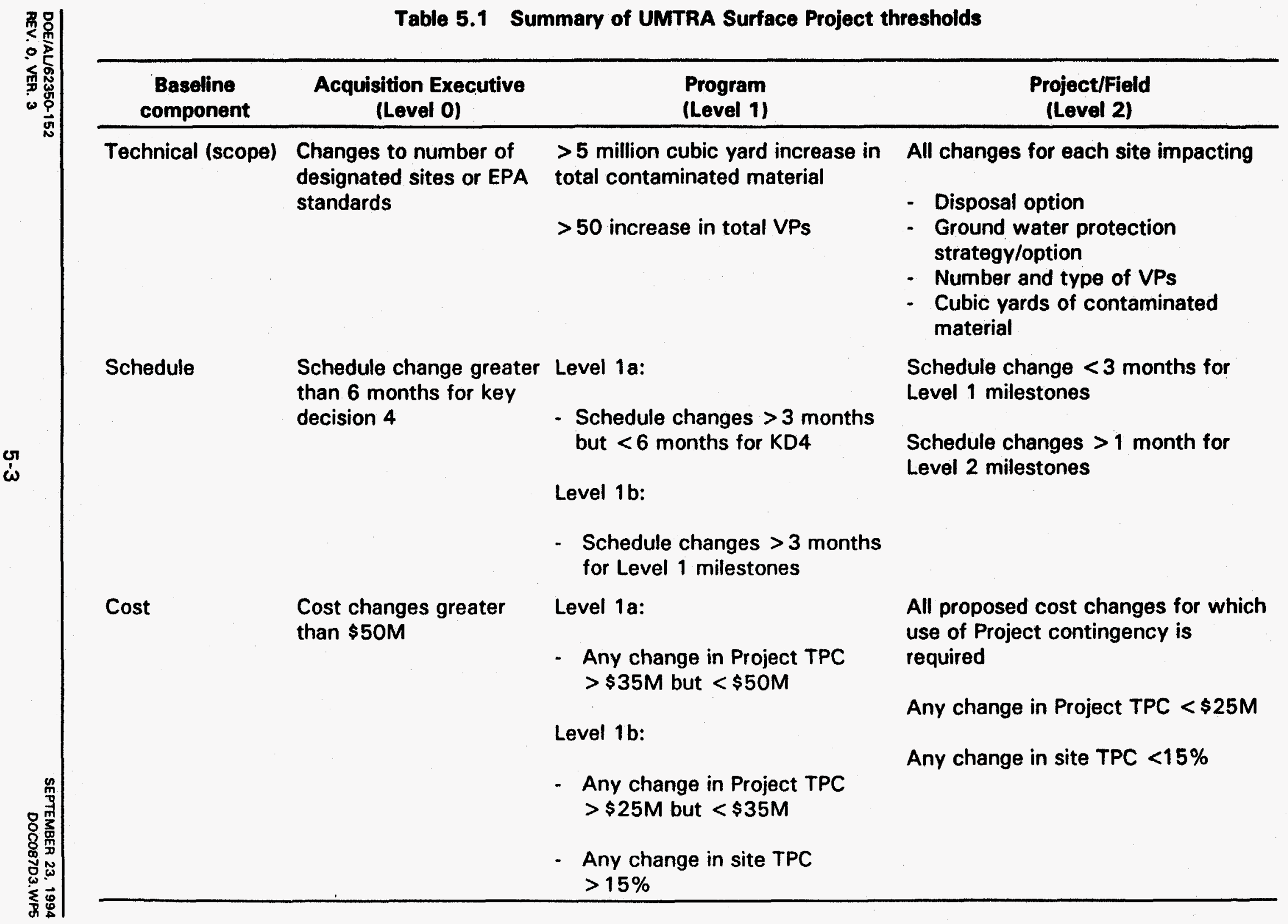


- Project-wide use of the Project master schedule.

- Procedures for coordinated schedule planning, maintenance, and status reporting (DOE, 1993b).

- Strict traceability throughout the schedule hierarchy with appropriate PWBS codes.

- Milestones in subordinate schedules that also appear in higher-level schedules.

- Project Manager approval of contractor schedules.

In accordance with the Project charter, the Project Office and the Office of Environmental Restoration (EM-40) jointly develop a set of milestones for each upcoming fiscal year. Monitored by DOE-HO, these milestones assist EM-4O in carrying out its program management responsibilities. Typically, these milestones represent the initiation or completion of key site activities; their status is reported to EM-40 through the PTS.

\subsubsection{Technical Baseline Control}

Changes to the technical baseline must occur through formal change control procedures. Technical baseline changes typically are driven by items beyond Project Office control (e.g., increases in tailings quantities, changes in EPA standards, additions or changes to existing DOE Orders, and changes in state permitting requirements). Changes to the technical baseline are controlled and documented through the Project configuration management system (Section 8.0).

\subsection{FUNDS CONTROL}

The objective of funds control is to use allocated funds effectively to accomplish the work for which they were appropriated, without additional funds. As part of the process, the Project Office prepares an annual DOE-AL funding plan approved by DOE-AL and maintains an obligation tracking system. These are used to analyze planned and authorized spending and actual performance in terms of authorizations, obligations, commitments, expenditures, and contingency.

The Project funding profile is based on the cost baseline and current budget authorizations for the fiscal year through the DOE-AL approved funding program. 


\subsection{RISK MANAGEMENT}

\subsubsection{Sources of risk}

Managing 20 major construction projects at 24 processing sites and approximately $\mathbf{5 0 0 0}$ smaller construction activities at vicinity properties creates a dynamic environment with considerable cost and schedule sensitivity. Furthermore, UMTRCA requirements, the NEPA process, the number of Project participants, budget constraints, the political environment, and technological considerations compound the situation. The Project conducts risk meetings twice a year; contractors and the Project Office Staff identify potential risks to the TPC and assign impact estimates and probabilities of occurrence. Contingency funds in the budget mitigate risk to the TPC. The Project Office mitigates risk to the project schedule by focusing on individual site schedules and the total project schedule. The Project Office conducts a monthly Project critical issues meeting at which task and site managers from all areas of the UMTRA Project organization meet to identify and discuss issues that could threaten site or Project schedules. Float and critical path analyses are performed, and Project activities are prioritized within the limits of Project resources.

\subsubsection{Contingency control}

Congressional funding, less the baselined work, determines contingency availability during each fiscal year. The original fiscal year budget plan (including the contingency) is revised to reflect the authorization. Application of the contingency requires $C C B$ recommendation and the Project Manager's approval.

If contingency is applied to an outyear requirement, the Project budget for the concerned fiscal year is increased and the contingency is reduced by the amount of application. The planned fiscal year budget submission is reevaluated to determine whether the remaining contingency is adequate. 


\subsection{INFORMATION AND REPORTING}

\subsection{OBJECTIVE}

The Project Office conducts a formal technical and management information and reporting program. The objective of the program is to ensure that accurate, timely, thorough, orderly, and meaningful Project information is disseminated to the UMTRA Project Manager and staff, DOE-HO, Project participants, and the public. This program is designed to promote timely, informed decision making and awareness of Project status and achievements.

\subsection{TECHNICAL INFORMATION}

The Project Office and contractors prepare technical documents related to development of the technical approach as well as development, implementation, control, and status of the technical design. The Project Office facilitates sharing technical information among the participants and promotes technology transfer to the private sector. An attachment to this document lists the primary technical documents prepared by the Project.

\subsection{MANAGEMENT INFORMATION}

The Project Office prepares and updates Project planning and management documents in accordance with DOE Order 4700.1. Project Management System. These documents delineate the organization and management systems for the Project and guide contractors in developing and maintaining planning and management systems. Table 6.1 lists Project Office and contractor-prepared Project planning and management documents. The Project Office also gathers and exchanges management information through meetings and reviews (Table 6.2).

\subsection{PROJECT REPORTING}

\subsubsection{Internal reporting}

Internal reports update the Project Manager and the Project Office staff on Surface Project cost, schedule, and technical status. The Project Office and participating contractors negotiate variance threshold tasks on an exception-toplan basis. Narratives from the variance analyses are included in reports to the Project Office. The TAC IPMS Group prepares the reports, integrating contractor data and the activities of cooperating agencies, local governments, public groups/task forces, and other organizations with Project involvement or interface. Table 6.3 lists the internal reports prepared for Project management and the contractor reports that support them. A process management team (PMT) is reviewing data collection and reporting. This team is comprised of Project Office, TAC, RAC and DOE contracts personnel. 
Table 6.1 UMTRA Surface Project planning and management documents

\begin{tabular}{|c|c|c|}
\hline Report/document & Content & Frequency \\
\hline \multicolumn{3}{|l|}{ Project management } \\
\hline Project charter & $\begin{array}{l}\text { Organizational responsibilities, } \\
\text { interfaces and policies for managing } \\
\text { the Project. }\end{array}$ & Once; revised as required \\
\hline Project plan & $\begin{array}{l}\text { Summary description, mission, } \\
\text { objectives, baseline, and acquisition } \\
\text { strategy. }\end{array}$ & Once; revised as required \\
\hline Project management plan & $\begin{array}{l}\text { Organizational responsibilities, } \\
\text { interfaces, workplan, and policies } \\
\text { for managing the Project. }\end{array}$ & Once; reviewed annually \\
\hline Acquisition strategy plan & $\begin{array}{l}\text { Concept for implementing } \\
\text { contracting structure. }\end{array}$ & Once; revised as required \\
\hline IPMS description & $\begin{array}{l}\text { Methods and procedures to manage } \\
\text { the Project work. }\end{array}$ & Once; revised as required \\
\hline Project WBS dictionary & $\begin{array}{l}\text { PWBS extended to include all } \\
\text { contract documents. }\end{array}$ & Once; revised as required \\
\hline $\begin{array}{l}\text { Project document control } \\
\text { system manual }\end{array}$ & Document disposition. & Once; revised as needed \\
\hline $\begin{array}{l}\text { Public Information plan and } \\
\text { public participation plan }\end{array}$ & $\begin{array}{l}\text { Methods and procedures to } \\
\text { promote public involvement in the } \\
\text { decision-making process. }\end{array}$ & Once; revised annually \\
\hline \multicolumn{3}{|l|}{ Contractor } \\
\hline Management plan & $\begin{array}{l}\text { Summary of contractor } \\
\text { organizational roles and } \\
\text { responsibilities; management } \\
\text { system description of policies, } \\
\text { methods, and procedures used by } \\
\text { the contractor to manage work. }\end{array}$ & Once \\
\hline CWBS Dictionary & $\begin{array}{l}\text { Contractor WBS for the task } \\
\text { agreement contract extended from } \\
\text { the PWBS, with definitions for each } \\
\text { element in the management plan. }\end{array}$ & $\begin{array}{l}\text { Once; revised as authorized } \\
\text { in negotiated task } \\
\text { agreement }\end{array}$ \\
\hline
\end{tabular}


Table 6.2 UMTRA Surface Project status and review meetings

\begin{tabular}{|c|c|c|c|}
\hline Meeting & Purpose & Participants & Frequency \\
\hline $\begin{array}{l}\text { UMTRA Project } \\
\text { Office staff }\end{array}$ & $\begin{array}{l}\text { Coordinate Project Office } \\
\text { activities }\end{array}$ & Project Office personnel & Twice weekly \\
\hline $\begin{array}{l}\text { Project Critical } \\
\text { Issues Meeting }\end{array}$ & $\begin{array}{l}\text { Identify issues that could } \\
\text { negatively impact timely, } \\
\text { successful completion of } \\
\text { the Project }\end{array}$ & $\begin{array}{l}\text { Project Office and } \\
\text { contractors }\end{array}$ & Monthly \\
\hline $\begin{array}{l}\text { DOE/TAC senior } \\
\text { management }\end{array}$ & $\begin{array}{l}\text { TAC presents status to the } \\
\text { Project Office }\end{array}$ & $\begin{array}{l}\text { DOE Project Manager } \\
\text { and group leaders, TAC } \\
\text { site and functional } \\
\text { managers }\end{array}$ & Monthly \\
\hline $\begin{array}{l}\text { DOE/RAC senior } \\
\text { management }\end{array}$ & $\begin{array}{l}\text { RAC presents status to the } \\
\text { Project Office }\end{array}$ & $\begin{array}{l}\text { DOE Project Manager } \\
\text { and group leaders, RAC } \\
\text { site and functional } \\
\text { managers }\end{array}$ & Monthly \\
\hline $\mathrm{CCB}$ & $\begin{array}{l}\text { Review baseline change } \\
\text { requests and approve or } \\
\text { disapprove }\end{array}$ & $\begin{array}{l}\text { Project Office, } \\
\text { contractors }\end{array}$ & Monthly \\
\hline $\begin{array}{l}\text { NRC management } \\
\text { review }\end{array}$ & $\begin{array}{l}\text { Review status of NRC } \\
\text { document reviews }\end{array}$ & $\begin{array}{l}\text { Project Office, } \\
\text { TAC/RAC, NRC }\end{array}$ & Periodically \\
\hline $\begin{array}{l}\text { Program office } \\
\text { review }\end{array}$ & $\begin{array}{l}\text { Project Office presents } \\
\text { Project status to program } \\
\text { office }\end{array}$ & $\begin{array}{l}\text { Program Office, Project } \\
\text { Office, Project } \\
\text { participants }\end{array}$ & $\begin{array}{l}\text { Semi-annually (mid- } \\
\text { year, year-end) }\end{array}$ \\
\hline $\begin{array}{l}\text { States } / \text { Tribes } \\
\text { coordination }\end{array}$ & $\begin{array}{l}\text { Cooperating agencies } \\
\text { exchange views on many } \\
\text { Project issues }\end{array}$ & $\begin{array}{l}\text { Project Office, TAC, } \\
\text { states, tribes, other } \\
\text { federal agencies }\end{array}$ & Annually \\
\hline $\begin{array}{l}\text { Bottoms-up } \\
\text { review }\end{array}$ & $\begin{array}{l}\text { Present and review Project } \\
\text { budget }\end{array}$ & $\begin{array}{l}\text { Project Office, } \\
\text { contractors }\end{array}$ & Annually \\
\hline
\end{tabular}


Table 6.3 Project Office internal reports

\begin{tabular}{|c|c|c|}
\hline Report/document & Content & Frequency \\
\hline $\begin{array}{l}\text { Summary level participant } \\
\text { progress report }\end{array}$ & $\begin{array}{l}\text { Data pages showing costs incurred; } \\
\text { budgeted values of scheduled and } \\
\text { completed work; EACs, and } \\
\text { performance variances by } \\
\text { contractor, by site, and by WBS. }\end{array}$ & Monthly \\
\hline Funds allocation plan & Status and distribution of funds. & $\begin{array}{l}\text { Annually; revised as } \\
\text { required }\end{array}$ \\
\hline Vicinity property progress report & $\begin{array}{l}\text { Cost and schedule status of vicinity } \\
\text { properties by site and by contractor. }\end{array}$ & Monthly \\
\hline Weekly activity report & Summary of activities by week. & Weekly \\
\hline \multicolumn{3}{|c|}{ SUPPORTING REPORTS PREPARED BY CONTRACTORS } \\
\hline Milestone plan & $\begin{array}{l}\text { Baseline schedule for selected WBS } \\
\text { element by month for current fiscal } \\
\text { year and by year thereafter. }\end{array}$ & $\begin{array}{l}\text { Annually; revised as } \\
\text { required }\end{array}$ \\
\hline $\begin{array}{l}\text { Milestone schedule and status } \\
\text { report }\end{array}$ & $\begin{array}{l}\text { Baseline schedule with progress and } \\
\text { analysis. }\end{array}$ & Monthly \\
\hline Cost plan & $\begin{array}{l}\text { Time-phased budget by month for } \\
\text { current FY and by FY thereafter. }\end{array}$ & $\begin{array}{l}\text { Annually; revised as } \\
\text { required }\end{array}$ \\
\hline $\begin{array}{l}\text { Cost performance report } \\
\text { (CPR) }\end{array}$ & $\begin{array}{l}\text { Costs incurred, budgeted values of } \\
\text { scheduled and completed work, } \\
\text { EACs, and performance variances by } \\
\text { WBS element. }\end{array}$ & Monthly \\
\hline IPMS report & $\begin{array}{l}\text { Equivalent to a site CPR and } \\
\text { provides basic data for the site, VP, } \\
\text { and Project progress reports. }\end{array}$ & Monthly \\
\hline Labor plan & $\begin{array}{l}\text { Planned labor application by } \\
\text { contractors in FTEs. }\end{array}$ & $\begin{array}{l}\text { Annually; revised as } \\
\text { required }\end{array}$ \\
\hline Milestone dictionary & $\begin{array}{l}\text { Complete definitions of EM-approved } \\
\text { milestones and Level } 2 \text { or key } \\
\text { supporting milestones. }\end{array}$ & Once; revised as required \\
\hline
\end{tabular}


If the PTM findings result in changes to the requried reports, the UMTRA Surface Project Management Plan and the Integrated Project Management System Description will be updated to reflect the changes.

\subsubsection{External reporting}

The PTS satisfies the main external reporting requirement for the Project. This monthly and quarterly computerized reporting system is available to the Office of Environmental Management at DOE-HQ, other government agencies, and the public for updates on the UMTRA Project. The PTS includes information from contractor reports, internal Project reports, and DOE-AL financial reports. The Project Manager's progress report (PMPR) is included quarterly as a PTS module.

Another external report is the UMTRA Project Annual Status Report. Distributed to all participants and stakeholders, this report summarizes the accomplishments of the previous year and plans for the next. Table 6.4 lists the UMTRA Project external reports. 
Table 6.4 Project Office external reports

\begin{tabular}{lll}
\hline \multicolumn{1}{c}{ Report/document } & \multicolumn{1}{c}{ Content } & \multicolumn{1}{c}{ Frequency } \\
\hline $\begin{array}{l}\text { Progress Tracking } \\
\text { System }\end{array}$ & $\begin{array}{l}\text { Project performance, DOE-HO } \\
\text { monitored milestones, variances and } \\
\text { funds status, including narrative to } \\
\text { support data. }\end{array}$ & Monthly \\
Project Manager's & $\begin{array}{l}\text { Summary of funding/cost status, } \\
\text { significant emerging trends, and } \\
\text { problems and solutions. }\end{array}$ & $\begin{array}{l}\text { Quarterly, as a module of } \\
\text { the Progress Tracking } \\
\text { System }\end{array}$ \\
Annual status report & $\begin{array}{l}\text { Summary of significant } \\
\text { accomplishments, status of designated } \\
\text { sites, and plans for the following year. }\end{array}$ & \begin{tabular}{l} 
Annually (FY) \\
\hline
\end{tabular} \\
\hline
\end{tabular}




\subsection{SYSTEMS ENGINEERING}

\section{$7.1 \quad$ INTRODUCTION}

Systems engineering is a process whereby a sequence of activities and decisions transform an identified mission into a description of system performance parameters and a preferred system configuration. A major element of conventional systems engineering focuses on products, hardware, and related procurement activities. While the UMTRA Project neither develops nor procures products or hardware as a major function, the Project does adopt many systems engineering concepts and attributes. The systems engineering element applied to UMTRA Project remedial action ensures each site remediation option is reviewed for reliability, technical viability, and cost effectiveness. In turn, this information is reflected in the RAC final design drawings, and in construction, and is ultimately defined in as-built LTSM drawings. Key aspects of the design include the ground water protection strategy and disposal cell longevity requirements, which determine the monitoring and maintenance requirements.

\subsection{PURPOSE}

The systems engineering process is consistent with the complexity of performing remedial action activities at UMTRA Project sites. The primary role of systems engineering is to ensure that the many and diverse technical activities involved in cleanup and disposal of residual radioactive material at a site are integrated and compatible with management controls.

Systems engineering maintains the following Surface Project objectives:

- Ensure systematic planning and control of an integrated engineering effort to achieve the Project technical requirements.

- Ensure appropriate supporting disciplines, including environmental, health and safety concerns, and maintenance activities are integrated into the total design effort.

- Integrate related technical parameters and ensure that interfaces are compatible.

- Measure progress in achieving technical requirements, including early identification of problems and high-risk areas.

\subsection{PROJECT OPERATION}

The UMTRA Project Manager directs and controls contractor-performed engineering efforts through the contractual process. In addition, the UMTRA 
Project Manager controls the contractor effort by reviewing approving contractor management plans, selected reports, and engineering documents.

At the Project level, the systems engineering effort includes the following plans and activities:

- Participant overview/concurrence. To meet provisions of the UMTRCA, participants (e.g., NRC, states, and tribes) provide overview and/or concurrence with designated project activities. This provides both internal and external engineering controls with regard to a site's progress toward stabilization and meeting the prescribed EPA standards. These efforts are integrated through close coordination with the various participants.

- Acquisition strategy plan. Supporting contractors are selected based on their technical expertise. Scope-of-work documents for these contractors establish a series of checks and balances whereby one contractor reviews the efforts of another to ensure that a technical activity follows the plan approved by the Project Office.

- Project plans. Critical activities of Project operation are further detailed in the project planning documents. These plans assign responsibilities and provide a level of detail that promote the basic precepts of controlling and integrating all relevant project activities. The Technical Approach Document (DOE, 1989) guides the Project testing, evaluation, and engineering efforts.

- Project scheduling. The basic project planning document is the IPMS schedule, which captures the total flow of Project activities. This schedule establishes the framework for contractor subtier schedules.

- Project work breakdown structure. The Project Office identifies and defines technical elements of the PWBS, interfaces among PWBS elements, and contractors responsible for accomplishment of designated tasks. The Project Office reviews the contract work breakdown structure submitted by each contractor to ensure the work definition relates directly to the PWBS. The Project Office analyzes risks associated with related cost, schedule, and technical parameters to identify critical areas and needs. Each contractor establishes internal procedures to identify, define, control, and communicate the statues of required interfaces.

\subsection{PROGRESS REVIEWS}

The sufficiency of the engineering effort is provided through periodic design and value engineering reviews for each site. The Project Office, TAC, RACs, NRC, and affected states and tribes participate in these reviews. The reviews assess progress against technical requirements and plans.

Design and value engineering reviews assess technical adequacy and design cost-effectiveness and coordinate design review activities. These reviews 
include independent reviews, adequacy assessments, and cost effectiveness analyses based on acceptable design alternatives. Design alternatives are based upon the requirements established by the EPA, DOE Orders, state laws and agreements, and other performance parameters which establish the design basis document (DBD) protocol. The Technical Approach Document (DOE, 1989) provides guidance for design and construction reviews. These reviews correspond with each significant phase of a site or VP remedial action. The results of these design and value engineering reviews are reflected in preliminary through final long-term surveillance activities. DOE and contractor personnel continue this interactive process throughout the PWBS, defining UMTRA Project products (e.g. functional activities).

\subsection{ENGINEERING INTEGRATION}

The systems engineering effort integrates and sequences Project activities and discussions. This interactive process continues at progressively lower PWBS levels to provide definitive descriptions of UMTRA Project products and functional activities.

The TAC prepares conceptual designs for site remediation. The Project Office approves and issues the designs to the RAC. As the RAC proceeds with design, interim deliverables (at 30 and 60 percent of completion) are submitted to the Project Office for review. The TAC reviews the designs for constructability, cost effectiveness, and consistency with site-specific ground water protection strategies. Systems engineering efforts support the establishment of configuration baseline management for each site or activity. 


\subsection{CONFIGURATION MANAGEMENT}

\section{$8.1 \quad$ INTRODUCTION}

Configuration management is a project management tool used by the UMTRA Project to determine and control baselines; document that all relevant features of a site are identified; and ensure that all relevant design documentation is identified, reviewed, and approved. Configuration management ensures that all work, including changes, is directed toward completing the UMTRA Project mission achieving (NRC licensing). The contractors' management plans include the applicable configuration management elements as defined by DOE Order 4700.1. Project Management System.

For the UMTRA Project, configuration management applies to functional requirements, site characterization, preliminary design, final design, all construction changes, and the surveillance and maintenance/turnover report (commonly referred to as the LTSP).

\subsection{CONFIGURATION MANAGEMENT PLAN}

Each contractor participating in the engineering effort is required to prepare and maintain a configuration management plan that integrates with its approved Management Plan. The configuration management plan includes the following:

- Systematic identification and control of documents that must be included in the configuration management programmatic baseline.

- The status of a proposed change.

- The status of change implementation.

- An auditable decision trail of changes.

- Provisions for maintaining all completed configuration management programmatic baseline documents.

The configuration management plan also establishes controls to document DOE and contractor approval of all changes to site technical baseline elements. Configuration management procedures maintain traceability of all changes from the initial functional requirements baseline to the site completion report (Figure 8.1). The DOE Project Office and the TAC are responsible for selecting specific data elements, choosing record and report formats, determining acceptability of these records, and retaining them. 


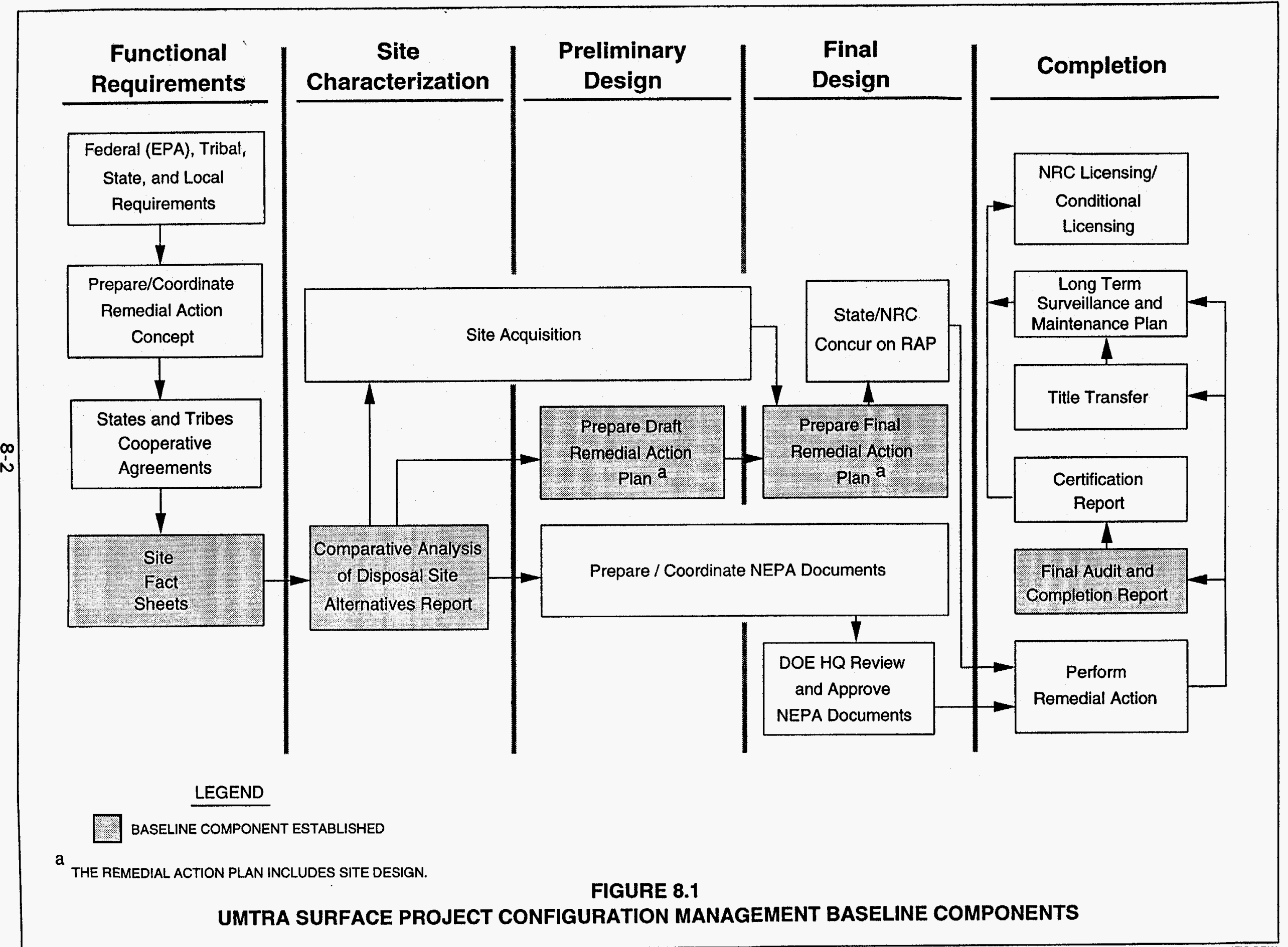




\subsection{CONFIGURATION CONTROL}

\subsubsection{Technical baseline documentation}

The technical baseline documentation for the UMTRA Project follows the stages illustrated in Figure 8.1. The completion of each stage (e.g., completion of site characterization with a comparative analysis of disposal site alternatives report (CADSAR)) is the basis for change control in the next stage (e.g., preliminary design). The highlighted boxes in Figure $\mathbf{8 . 1}$ identify specific documents that represent a completed stage.

Functional requirements. This stage documents the federal, state, tribal, and local regulations, laws, and agreements governing the remediation of the processing site. These requirements define the type of remediation efforts required and a preliminary schedule. Site fact sheets verify this stage is completed.

Site characterization. This stage documents the plans, results, and design options identified by site characterization. The site characterization report guides preliminary design and estimates costs and schedules associated with the selected remediation design options. The CADSAR verifies this stage is completed.

Preliminary design: This stage documents the site's preliminary (or initial) design. A draft RAP verifies this stage is complete. The draft RAP describes the preliminary design, references all relevant design documents, and lists sitespecific cost and schedule estimates.

Final design. This stage documents the site's final design for remedial action. The completed RAP includes a description of final design, references to all relevant design and site acquisition documents and NEPA requirements, and final site-specific cost and schedule estimates. A final RAP verifies this stage is completed.

Completion. This stage defines the completion of site remedial action, verified in the completion report. The completion report contains as-built drawings, final topography surveys, and VP maps. The LTSP establishes the long-term surveillance instructions for identifying changes in disposal site conditions. These instructions ensure the disposal site continues to function as designed. While long-term surveillance is not a function of the UMTRA Project, the LTSP must be approved by NRC prior to licensing. Any changes to site conditions after finalization of the completion report but before licensing must be documented in the final LTSP.

Project configuration control ensures systematic evaluation, coordination, approval/disapproval, and implementation of technical changes in baseline documents. Changes affecting this configuration must be limited to those 
which are necessary or offer significant benefits to the UMTRA Project. The following changes meet these criteria:

- Those required to correct deficiencies.

- Those required to incorporate approved changes in operational or logistic support characteristics.

- Those which create substantial life-cycle cost savings.

- Those required to correct safety deficiencies.

\subsubsection{Technical baseline control process}

A project interface document (PID) accompanies every proposed design or construction feature change submitted to the Project Office for review and approval. The PID identifies the proposed change and classifies the change (Class I, II, or III). A Class I change may affect compliance with EPA standards. Class I changes are reflected in a modification to the RAP and could ultimately require a change in the cooperative agreement. The NRC and the participating state and/or tribe must concur on all Class I changes. A Class II change is a change to any permanent construction feature that does not clearly affect compliance with EPA standards. Class II changes do not require concurrence by participating states or tribes but are forwarded to the regulatory agencies for review to ensure the changes have been classified correctly. A Class II change will not require a modification to the RAP or the cooperative agreement. A Class III change is a change to temporary features that does not affect the stabilization design of the tailings pile. Class III changes do not require cooperating agency concurrence. However, the TAC reviews Class III changes to ensure they do not compromise commitments.

\subsection{DOCUMENT CONTROL}

The UMTRA Project Document Control Center (UPDCC) records, files, and controls technical baseline documents. Configuration management ensures that only the latest, approved revisions of drawings, procedures, and similar materials are used by UMTRA Project personnel. The DOE Project Office, TAC, and RAC document centers share these responsibilities.

\subsection{RECORDS MANAGEMENT}

Records management maintains documents and records identified by document control and other affected parties. These records include all technical baseline documents, design changes, test and calibration data, interim review calculations, and similar materials. The DOE retains these records in designated repositories to provide auditable results of the total process in addition to proof of performance. All records are retained in accordance with DOE Order 1324.2A, Records Disposition. 


\subsection{QUALITY ASSURANCE}

Managing surface remedial action so as to meet required standards and satisfying the expectations of the Project participants and the public are basic in the UMTRA Project Office mission. To accomplish these objectives, the UMTRA Project Office established an effective QA program under the direction of the UMTRA Technical Support Group Leader. This program ensures surface remedial action meets federal performance standards and federal, state, and local requirements for licensing disposal cells at a cost consistent with sound economic planning.

\subsection{QUALITY ASSURANCE PROGRAM}

The UMTRA Project Office has established and implemented a QA program consistent with the requirements of DOE Order 5700.6C, Quality Assurance, and covers the applicable portions of the 11 QA elements for environmental monitoring and surveillance programs described in DOE Order 5400.1. General Environmental Protection Program. The UMTRA Project QA program is designed to control the quality of Project activities that may impact safety and health of workers or the public, the quality of the environment, or the success of the Project. The UMTRA Project QA program is described in the UMTRA Project OA Program Plan (QAPP) (DOE, 1993c). The Project Office also conducts internal appraisals in accordance with DOE Order 5482.1B, Environment, Safety, and Health Appraisal Program. This subset of the QA program is further discussed in Section 10.0 of this plan.

The DOE UMTRA Project Manager has overall responsibility for implementing the UMTRA Project QA program and for ensuring that UMTRA Project contractors develop and implement QA programs consistent with the UMTRA Project QAPP. The Project Manager meets these responsibilities with the support of the UMTRA QA manager. The UMTRA OA manager is responsible for directly overseeing and controlling all Project Office $Q A$ activities and interfaces directly with the TAC and RAC QA managers. The Project Office promotes the principles of total quality management; therefore, the UMTRA Project QA program is intended to reach to every employee on the UMTRA Project. These employees are responsible for achieving at least a specified level of quality in their work and for striving for continual improvement.

\subsection{PROGRAM IMPLEMENTATION}

The RAC and TAC are contractually required to implement the UMTRA Project QA plan by developing QA programs commensurate with their activities. To assure the quality of work on surface remedial action and associated activities is not jeopardized, the Project Office conducts an active QA oversight program. The RAC is responsible for documenting, implementing. and operating sitespecific programs for surface remedial action in accordance with its DOEapproved QAPP. The Project Office ensures RAC programs are implemented and work is performed properly through TAC QA manager conduct operational 
readiness evaluations and in-process quality control audits of RAC operations at each site.

The UMTRA Project QA program extends to the generation, acquisition, and use of environmental data. The UMTRA Project QA manager is responsible for the UMTRA independent data verification program. The RAC and the TAC verify data independently. All environmental data, collection methods, and analyses are reviewed for adequacy, accuracy, and completeness. In addition, the Project Office instructs the TAC to conduct $Q A$ audits of subcontractor analytical laboratories to verify compliance with technical and $Q A$ requirements. The UMTRA Project environmental data verification programs are discussed in detail in the UMTRA Project Environmental Monitoring Plan (DOE, 1992a) and the Environmental Protection Implementation Plan (DOE, 1993d). 


\subsection{ENVIRONMENT, SAFETY AND HEALTH}

The UMTRA Project Office mission is to minimize or eliminate environmental and public health hazards associated with uranium mill tailings. The UMTRA Surface Project achieves these objectives by protecting public health and safety and the environment; ensuring the safety and health of workers; complying with all applicable federal, state, and local laws, regulations, orders, and permits; and applying best management practices. The UMTRA Project Office established an effective environment, safety, and health (ES\&H) program under the direction of the UMTRA Technical Support Group Leader. This program will ensure that surface remedial action meets or exceeds performance standards; federal, state, and local ES\&H standards; and other applicable requirements at a cost consistent with sound economic planning.

\subsection{ENVIRONMENT, SAFETY AND HEALTH PROGRAM}

The UMTRA Project Office ES\&H program is consistent with a graded approach to meet the requirements of DOE Order 5480.1B, DOE Order 5482.1B, and other applicable DOE 5400 and 5480 series Orders. The UMTRA Project ES\&H program, including specific ES\&H goals, is described in the UMTRA Project ES\&H plan (DOE, 1992b), which satisfies the DOE Order 4700.1 requirement for an ES\&H protection implementation plan.

The UMTRA Project ES\&H program also satisfies the requirements of DOE Order 5440.1E, National Environmental Policy Act, for complying with the National Environmental Policy Act (NEPA) (42 U.S.C. \$4321 et seq.). The Surface Project NEPA implementation program is detailed in Procedure for Preparation, Printing and Distribution of UMTRA Project NEPA Documents (DOE, 1988).

The DOE UMTRA Project Manager has overall responsibility for implementing the UMTRA Project ES\&H program and for ensuring that UMTRA contractors develop and implement ES\&H programs consistent with the UMTRA Project ES\&H Plan. The UMTRA Project ES\&H Goal Statement (DOE, 1992c) describes the Project Office's commitment to implementing a sound ES\&H Program. The Project Manager fulfills these responsibilities with the support of the UMTRA Technical Support Group. The UMTRA ES\&H Manager and radiation protection manager are responsible for directly overseeing and controlling all Project Office ES\&H activities and interface directly with the RAC and TAC ES\&H managers. The UMTRA NEPA manager is responsible for overseeing the UMTRA NEPA implementation program.

\subsection{PROGRAM IMPLEMENTATION}

Directed by the Project Office, the TAC prepares NEPA documentation for UMTRA Project activities. Before site-specific surface remedial action begins, proposed actions are evaluated to determine the level of NEPA documentation required. Site-specific environmental impact statements or environmental 
assessments, as appropriate, examine the impact of the proposed actions and alternatives.

Safety analyses and risk reduction are basic to the UMTRA ES\&H program. The UMTRA Project Office has determined that UMTRA sites are radiological rather than nuclear facilities, in accordance with DOE guidance. The RAC and TAC are contractually required to implement the UMTRA Project ES\&H plan by developing ES\&H programs appropriate to the radiological, construction, and transportation hazards associated with their activities (Figure 10.1). The UMTRA Technical Support Group Leader approves contractor ES\&H program implementation plans.

The Project Office conducts an active ES\&H oversight program to ensure that surface remedial action and associated activities protect DOE and contractor employees, the general public, and the environment. This program also reduces the potential for delays or interruptions caused by ES\&H incidents. The RAC is responsible for documenting, implementing, and operating site-specific ES\&H programs for surface remedial action in accordance with its DOE-approved ES\&H plan. The Project Office ensures the RAC programs are implemented and work is performed properly by having the TAC, under the UMTRA ES\&H and Radiation Protection Managers' oversight, conduct operational readiness evaluations, and safety and health, radiological, and environmental appraisals of the RAC's site operations. The Project Office oversight program is also supplemented by DOE-AL ES\&H technical appraisals. 


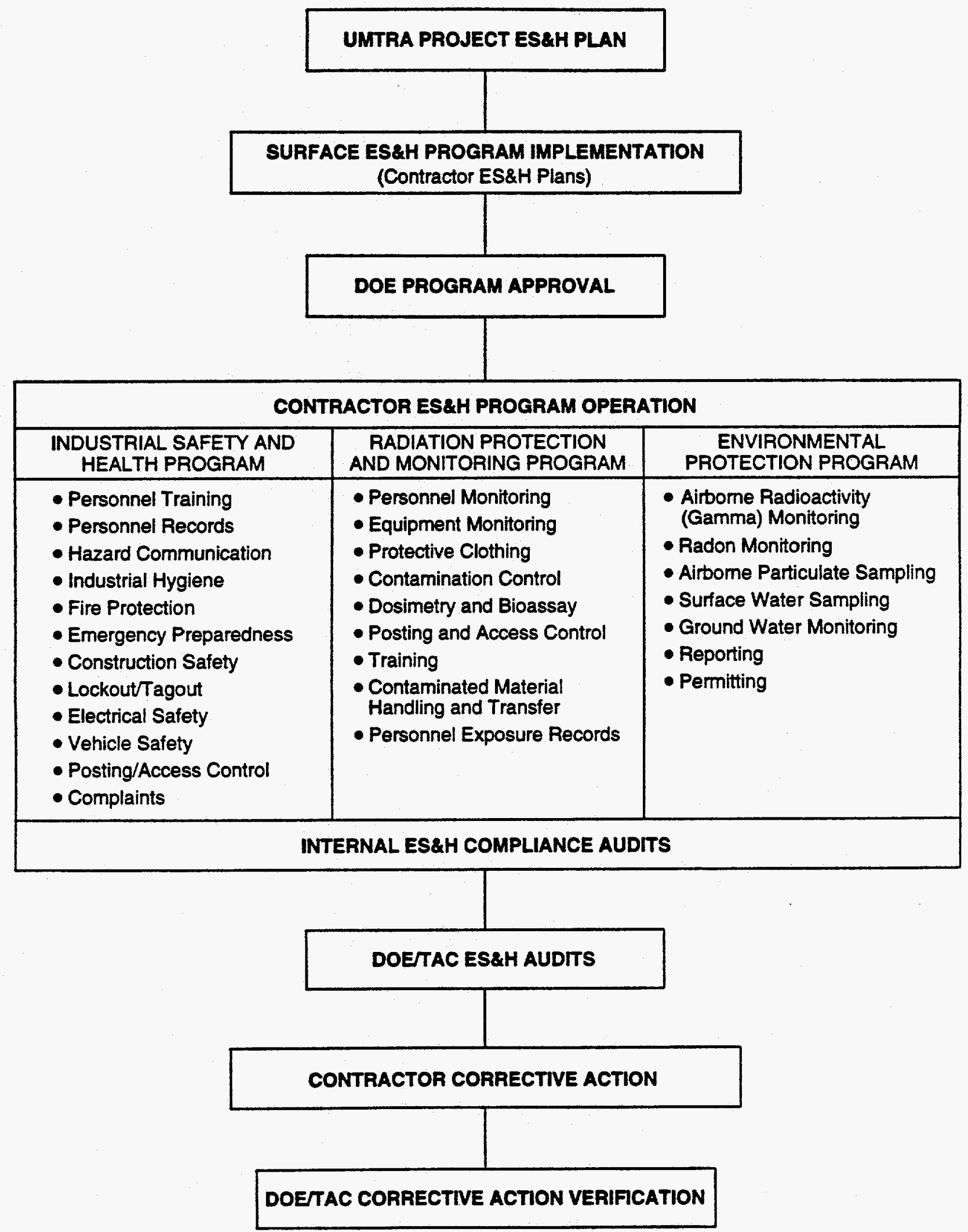

FIGURE 10.1

UMTRA SURFACE PROJECT ES\&H PROGRAM 


\subsection{UTILITY SERVICES}

During the initial remedial action planning and design effort, the TAC searches public and private sources to locate all existing utility conveyances that could impact site characterization or remedial action activities. Every city, county, and state agency that could have information regarding existing pipes, ducts, transmission lines, and cables on or near the processing and disposal site (if appropriate) is contacted.

Once the information is evaluated, the TAC prepares a memorandum documenting the investigation and a composite map showing existing utilities at the site. The TAC uses this information to identify areas to avoid (e.g., when drilling). The map is included in the draft RAP and the RAC uses this information in its site design. If the utilities hinder effective site stabilization, they are removed, relocated, or abandoned by the individual utility company.

The availability of utilities during remedial action is considered in the final site design. The RAC arranges for temporary water, electricity, telephone, and gas or butane services, in the main subcontracting bid package. After remedial action is complete, the temporary utility services are terminated because permanent utilities are not required during surveillance and maintenance. If utilities are needed after remedial action, temporary arrangements are made. A similar process exists for vicinity property design and remedial action with the RAC subcontractor in charge of all work. 


\subsection{REFERENCES}

DOE (U.S. Department of Energy), 1994. Vicinity Properties Management and Implementation Manual, UMTRA - DOE/AL-050601 prepared by the U.S. Department of Energy, UMTRA Project Office, Albuquerque Operations Office, Albuquerque, New Mexico.

DOE (U.S. Department of Energy), 1993a. Uranium Mill Tailings Remedial Action (UMTRA) Surface Project Plan, DOE/AL/62350-35F, Revision 1, prepared by the U.S. Department of Energy, UMTRA Project Office, Albuquerque Operations Office, Albuquerque, New Mexico.

DOE (U.S. Department of Energy), 1993b. Integrated Project Management System Description, UMTRA-DOE/AL - 400126.0000, prepared by the U.S. Department of Energy, UMTRA Project Office, Albuquerque Operations Office, Albuquerque, New Mexico.

DOE (U.S. Department of Energy), 1993c. UMTRA Project Office Quality Assurance Program Plan, UMTRA-DOE/AL-62350-76, Revision 5, prepared by the U.S. Department of Energy, UMTRA Project Office, Albuquerque Operations Office, Albuquerque, New Mexico.

DOE (U.S. Department of Energy), 1993d. UMTRA Project Environmental Protection Implementation Plan, UMTRA-DOE/AL-62350-79, prepared by the U.S. Department of Energy, UMTRA Project Office, Albuquerque Operations Office, Albuquerque, New Mexico.

DOE (U.S. Department of Energy), 1992a. UMTRA Project Environmental Monitoring Plan, UMTRA-DOE/AL-150129.0000, prepared by the U.S. Department of Energy, UMTRA Project Office, Albuquerque Operations Office, Albuquerque, New Mexico.

DOE (U.S. Department of Energy). 1992b. UMTRA Project Environmental, Health, and Safety Plan, UMTRA-DOE/AL-150224.0006, prepared by the U.S. Department of Energy, UMTRA Project Office, Albuquerque Operations Office, Albuquerque, New Mexico.

DOE (U.S. Department of Energy), 1992c. UMTRA Project Environmental, Safety, and Health Goal Statement, May 1992, prepared by the U.S. Department of Energy, UMTRA Project Office, Albuquerque Operations Office, Albuquerque, New Mexico.

DOE (U.S. Department of Energy), 1989. Technical Approach Document, UMTRA DOE/AL-050425.0000, prepared by the U.S. Department of Energy, UMTRA Project Office, Albuquerque Operations Office, Albuquerque, New Mexico. 
DOE (U.S. Department of Energy), 1988. Procedure for Preparation, Printing, and Distribution of UMTRA Project National Environmental Policy Act Documents, UMTRA-DOE/AL-150127.000, Prepared by the U.S. Department of Energy, UMTRA Project Office, Albuquerque Operations Office, Albuquerque, New Mexico.

DOE (U.S. Department of Energy), 1986. Project Charter, UMTRA-DOE/AL 400124.0167, prepared by the U.S. Department of Energy, UMTRA Project Office, Albuquerque Operations Office, Albuquerque, New Mexico.

\section{CODE OF FEDERAL REGULATIONS}

10 CFR Part 40, "Domestic Licensing of Source Material," U.S. Nuclear Regulatory Commission (1994).

10 CFR Part 1021, "National Environmental Policy Act Implementing Procedures," U.S. Department of Energy (1994).

40 CFR Part 192, "Health and Environmental Protection Standards for Uranium and Thorium Mill Tailings," U.S. Environmental Protection Agency (1994).

40 CFR Parts 1500-1508, "Regulations for Implementing the Procedural Provisions for the National Environmental Policy Act," Council on Environmental Quality (1994).

\section{DOE ORDERS}

Order 1324.2A, change 1, April 9, 1992. Records Disposition, April 1992, U.S. Department of Energy, Office of Information Resources Management.

Order 4700.1, Change 1, 1992. Project Management System, June, 1992, U.S. Department of Energy, Office of Primary Interest, Project Management Division.

Order 5400.1, 1988. General Environmental Protection Program, November 8,1988, U.S. Department of Energy, Office of the Assistant Secretary for Environmental Safety and Health.

Order 5440.1E, 1992. National Environmental Policy Act, November 10, 1992, U.S. Department of Energy, Office of Environmental Safety and Health.

Order 5480.1B, 1993. Environment, Safety, and Health Program for DOE Operations, change 5. May 10, 1993, U.S. Department of Energy, Office of the Assistant Secretary for Environmental Safety and Health. 
Order 5482.1B, 1991. Environment, Safety, and Health Appraisal Program, November 18, 1991, U.S. Department of Energy, Office of Environmental Safety and Health.

Order 5700.6C, 1991. Quality Assurance, August 21, 1991, U.S. Department of Energy, Office of Environmental Safety and Health.

\section{DOE NOTICES}

Notice 4700.5, 1992. Project Control System Guidelines, August, 1992, U.S. Department of Energy, Office of Procurement, Assistance and Program Management, Project Management Division.

\section{UNITED STATES CODE}

42 USC $\$ 4321$ et seq., National Environmental Policy Act, January 1, 1970.

42 USC $\$ 7901$ et seq., Uranium Mill Tailings Radiation Control Act, November 8, 1978. 


\subsection{SUBMISSIONS AND APPROVAL}

This UMTRA Surface Project Management Plan is submitted by:

Charles A. Cormier, Acting UMTRA Project Manager

Uranium Mill Tailings Remedial Action Project Office

It is concurred with by:

Office of Environmental Management

The approved workload of the UMTRA Surface Project is stated in the Uranium Mill Tailings Radiation Control (42 USC $\$ 7901$ et seq.) The workload consists of planning, designing, and conducting remedial action at the 24 designated inactive uranium processing sites and associated vicinity properties (including those at Edgemont) in a safe and environmentally sound manner in cooperation with the states and Indian tribes. Remedial action must be performed in accordance with pertinent U.S. Environmental Protection Agency Standards, must be consistent with other applicable laws, and must have concurrence from the Nuclear Regulatory Commission.

Approved:

Bruce G. Twining, Manager

Albuquerque Operations Office 


\section{ATTACHMENT}

UMTRA SURFACE PROJECT PLANNING DOCUMENTATION 


\section{UMTRA SURFACE PROJECT PLANNING DOCUMENTATION}

The documents below are available in the Uranium Mill Tailings Remedial Action Project Document Control Center, UMTRA Project Office, Albuquerque Operations Office, Albuquerque, New Mexico.

\section{General Guidance Documents}

"Site Management Manual," UMTRA-DOE/AL-40005.0000

Documents the organizational and technical approach used to manage the activities required to stabilize and control the Project sites.

"Key Programmatic Steps and Activities for Implementing the Uranium Mill Tailings Remedial Action Program," UMTRA-DOE/AL-400129.0000

Presents basic procedures and key programmatic steps established to carry out sitespecific remedial action.

"Plan for Implementing EPA Standards for UMTRA Sites," UMTRA-DOE/AL-400724.0163 Presents Project procedures and testing and evaluation criteria for planning implementation of EPA standards.

"Technical Approach Document," UMTRA-DOE/AL-050425.0000

Describes the general technical approach and design criteria for preparing site remedial action plans and designs.

"Design Criteria for Stabilization of Inactive Uranium Mill Tailings Site,"

UMTRA-DOE/AL-050424.0049

Provides criteria for preparing RAC site designs.

"Outdoor Radon Monitoring Plan for the UMTRA Project Sites," UMTRA-DOE/

AL-150225.0000

Describes the monitoring schedules and methods used to measure ambient radon concentrations around UMTRA Project sites.

"Alternate Site Selection Process for UMTRA Project Sites," UMTRA-DOEI AL-200129.0007

Describes the procedures the Project Office, the NRC, and affected states or tribes must follow in selecting alternate sites for off-site disposal.

"Certification Plan for the UMTRA Project Processing Site," UMTRA-DOE/AL-400728.000 Establishes Project policies and procedures for site certification.

"Project Licensing Plan," UMTRA-DOE/AL-350124

Establishes the Project site licensing concept and describes the functions of participatory agencies. 
"Guidance for UMTRA Project Surveillance and Maintenance," UMTRA-DOE/

AL-350124.0000

Establishes the Project procedures for long-term surveillance and maintenance of disposal sites after remedial action is complete.

"Vicinity Properties Management and Implementation Manual," UMTRA-DOE/AL-050601 Describes Project policies and procedures for remedial action on vicinity properties.

"UMTRA Project Quality Assurance Plan," UMTRA-DOE/AL-62350-76 Establishes guidelines for Project participant QA programs.

"UMTRA Project Environmental, Health, and Safety Plan," UMTRA-DOE/AL-150224.0006 Identifies basic federal health and safety standards and special DOE requirements applicable to the Project environment, health, and safety program.

"Contents of Environmental Assessments Prepared for the UMTRA Project," UMTRADOE/AL-150126.0010 Identifies contents of environmental assessments.

"Contents of Environmental Impact Statements Prepared for the UMTRA Project," UMTRADOE/AL-150125.0006 Identifies contents of environmental impact statements.

"Procedure for Preparation, Printing, and Distribution of UMTRA Project National Environmental Policy Act Documents," UMTRA-DOE/AL-150127.0000

Identifies procedures for preparation, printing, and distribution of UMTRA NEPA documents.

\section{Site-Specific Documents}

Comparative Analysis of Disposal Site Alternatives Report

Provides the basis for agreement with affected states or tribes on preferred alternatives to remedial action; also provides agreement with the Nuclear Regulatory Commission that the preferred alternatives will meet the EPA standards.

Site NEPA Documentation Includes categorical exclusion, environmental assessments or environmental impact statements, findings of no significant impact or records of decision, and other documentation (e.g., floodplain assessment) required to comply with NEPA requirements for a site.

Remedial Action Plan

Identifies site activities and the design required to effect long-term stabilization and control of residual radioactive materials for each site. 
Site Surveillance and Maintenance Plan

Describes the surveillance and maintenance requirements for a disposal site after remedial action is complete; also provides the basis for obtaining the site license.

Economic Evaluation of Inactive Uranium Mill Tailings,

A series of studies conducted to determine the economic viability of reprocessing the tailings for recoverable uranium, vanadium, and molybdenum. The studies were conducted at Salt Lake City, Shiprock, Gunnison, Grand Junction, Old and New Rifle, Maybell, Riverton, Spook, Ambrosia Lake, Mexican Hat, Tuba City, and Durango.

The UMTRCA requires the Project to consider the reprocessing potential of the uranium tailings. Recovery of the residual minerals is permitted if it is consistent with remedial action. Additionally, reprocessing must be as cost effective as any other option before it is considered. Project Office economic evaluation studies conducted determined that tailings reprocessing was not economical. As a result, unless conditions change markedly, the Project Office no longer considers reprocessing a viable remedial action option. 